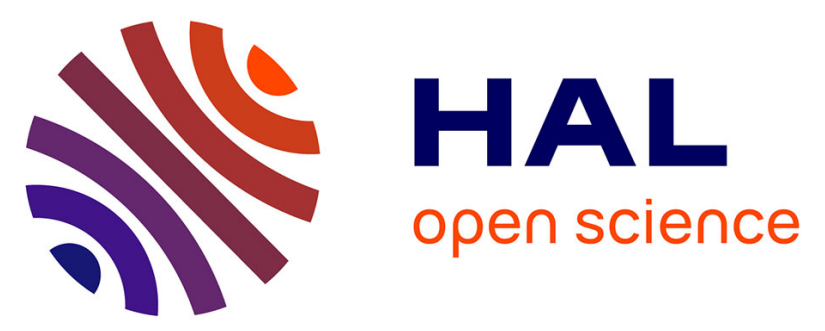

\title{
Allosteric Functional Switch of Neurokinin A-Mediated Signaling at the Neurokinin NK2 Receptor: Structural Exploration
}

Celine Valant, Emeline Maillet, Jean-Jacques Bourguignon, Bernard Bucher, Valérie Utard, Jean-Luc Galzi, Marcel Hibert

\section{To cite this version:}

Celine Valant, Emeline Maillet, Jean-Jacques Bourguignon, Bernard Bucher, Valérie Utard, et al.. Allosteric Functional Switch of Neurokinin A-Mediated Signaling at the Neurokinin NK2 Receptor: Structural Exploration. Journal of Medicinal Chemistry, 2009, 52 (19), pp.5999-6011. 10.1021/jm900671k . hal-02193663

\section{HAL Id: hal-02193663 \\ https://hal.science/hal-02193663}

Submitted on 25 Jul 2019

HAL is a multi-disciplinary open access archive for the deposit and dissemination of scientific research documents, whether they are published or not. The documents may come from teaching and research institutions in France or abroad, or from public or private research centers.
L'archive ouverte pluridisciplinaire HAL, est destinée au dépôt et à la diffusion de documents scientifiques de niveau recherche, publiés ou non, émanant des établissements d'enseignement et de recherche français ou étrangers, des laboratoires publics ou privés. 


\section{Allosteric Functional Switch of Neurokinin A-mediated}

2

\section{Signalling at the Neurokinin NK2 Receptor: Structural}

\section{Exploration}

Céline Valant, ${ }^{\S}$ Emeline Maillet,,${ }^{\triangleright}$ Jean-Jacques Bourguignon, ${ }^{\S}$ Bernard Bucher, ! Valérie Utard, ${ }^{\star}$ Jean-

Luc Galzi, ${ }^{\circledR}$ and Marcel Hibert. ${ }^{\S} *$

§ UMR UdS/CNRS 7200, Laboratoire d'innovation thérapeutique, and ' UMR UdS/CNRS 7213

Laboratoire de biophotonique et pharmacologie, Faculté de Pharmacie 74 route du Rhin BP60024, 67401 Illkirch - France, a FRE UdS/CNRS 3211, Institut de recherche de l'école de biotechnologie, ESBS, boulevard Sébastien Brant 67401 Illkirch - France.

e-mail mhibert@pharma.u-strasbg.fr

RECEIVED DATE (to be automatically inserted after your manuscript is accepted if required according to the journal that you are submitting your paper to)

CORRESPONDING AUTHOR FOOTNOTE *To whom correspondence should be addressed. Phone: +33390244232. Fax: +33390244310. E-mail mhibert@pharma.u-strasbg.fr

ABBREVIATIONS LIST FOOTNOTE. a Abbreviations: FRET, fluorescence resonance energy transfer; BRET, bioluminescence resonance energy transfer; GPCR, G-protein-coupled receptor; EGFP, enhanced green fluorescent protein; NK2R, NK2 receptor; NKA-Bo, NKA linked to the Bodipy fluorophore; NK2-EGFP, NK2 receptor expressed as a fusion protein with the enhanced green fluorescent protein on the N-terminal; 
1 ABSTRACT. The neurokinin NK2 receptor is known to pre-exist in equilibrium between at least three

2 states: resting-inactive, calcium-triggering and cAMP-producing. Its endogeneous ligand, NKA, mainly

3 induces the calcium response. Using a FRET ${ }^{\text {a }}$-based assay, we have previously discovered an allosteric

4 modulator of the NK2 receptor that has the unique ability to discriminate among the two signaling

5 pathways: Calcium-signaling is not affected while cAMP signaling is significantly decreased. A series

6 of compounds have been prepared and studied in order to better understand the structural determinants

7 of this allosteric functional switch of a GPCR. Most of them display the same allosteric profile, with

8 smooth pharmacomodulation. One compound however exhibits significantly improved modulatory

9 properties of NKA induced signaling when compared to the original modulator.

10 KEYWORDS. Allosteric ligands; FRET; NK2 neurokinin receptor, functional switch, structure-activity 11 relationship.

\section{MANUSCRIPT TEXT.}

Introduction. Allosterism is a well known process that has been extensively studied in enzymes and 15 in some receptors. However, the study of this phenomenon for G protein-coupled receptors $\left(\mathrm{GPCR}^{\mathrm{a}}\right)$ is 16 relatively recent, probably due to the lack of simple detection methods. ${ }^{1,2}$ Since allosteric interactions could be quite subtle, many ways of studying allosteric behaviors were established and can be used individually or in tandem. Among them, the study of the effect of an allosteric ligand on the dissociation of a labeled ligand to a receptor, which measures the ability of an allosteric ligand to alter the dissociation rate constant ( $\left.\mathrm{K}_{\mathrm{off}}\right)$ of the orthosteric labeled ligand in time, is one of the most sensitive, direct and unequivocal method to validate an allosteric interaction.

We have demonstrated that fluorescence resonance energy $\operatorname{transfer}^{3}$ (FRET) represents an efficient and informative way to study GPCR-ligand interaction. ${ }^{4}$ Indeed, a very specific and sensitive FRET signal can be observed when an appropriate fluorescent ligand binds to a GPCR fused to a fluorescent 
protein, such as enhanced green fluorescent protein (EGFP). ${ }^{5}$ Binding can be easily analyzed by a simple measurement of EGFP emission. We have used FRET-based binding analysis to study several GPCRs ${ }^{6}$ including the neurokinin A (NKA) receptor, known as NK2 receptor. In this particular case, FRET revealed that the recombinant human neurokinin NK2 receptor, in presence of NKA-Bo (NKA linked to Bodipy $\left.^{4,7}\right)$, exists in equilibrium between predominantly three states: inactive (R), calcium-triggering (conformation A1) characterized by a rapid association and dissociation of the endogeneous agonist NKA, and cAMP-producing (conformation A2), characterized by slow association and slow dissociation of the agonist.

We have screened 1,600 drug-like molecules issued from our laboratory in a FRET-based binding assay in order to find antagonist ligands. Interestingly, this study led to the discovery of compound $\mathbf{1}$ (Chart 1), a new allosteric ligand for the neurokinin NK2 receptor. This ligand exhibited the particularity of being a strong negative allosteric modulator for the cAMP-producing conformation (A2) while not affecting or slightly potentiating the calcium triggering conformation (A1) ${ }^{8}$ In fact, in the presence of 20 nM of NKA-Bo, the receptor was stabilized in a 30/70 ratio of A1/A2 conformations. Upon addition of $10 \mu \mathrm{M}$ of $\mathbf{1}$, still in presence of $20 \mathrm{nM}$ of NKA-Bo, the NK2 receptor was stabilized in a 50/50 ratio of A1/A2 conformations. Finally, addition of $50 \mu \mathrm{M}$ of 1 balances the receptor to a $95 / 5$ maximal ratio of A1/A2 conformations (Table 1). ${ }^{8}$

We report here the structure-activity relationship study around this allosteric functional switch of a GPCR, the neurokinin NK2 receptor, and characterize our best optimized hit, compound 16, in both calcium mobilization and cAMP accumulation assays.

\section{Methods}

Chemistry. The synthesis of 1, [N-benzyl,N-(2-naphthylmethyl)-amino]-acetonitrile (Chart 1), has previously been reported. ${ }^{89}$ Synthesis of 31 derivatives showing structural similarity to $\mathbf{1}$ was undertaken, based on the substitution of the three groups around the central tertiary amine. The 32 compounds were synthesized according to standard procedures (Scheme 1). Two methods were 
1 followed to obtain the whole set of compounds. Method A allowed the synthesis of 22 compounds (1-

$220 ; 31,32)$ by two successive steps, a reductive amination between an aldehyde and an amine exhibiting 3 the R2 group followed by an alkylation of the secondary amine. Further 8 compounds were synthesized 4 by converting the N,N-(2-methylnaphthyl-benzyl)-2-aminoethanoic acid $\mathbf{1 8}$ into bulky amides $\mathbf{2 5 - 2 8}$ or 5 bulky esters 21-24 in peptide coupling conditions. Method B was followed to synthesize two additional 6 compounds, by condensing first an aldehyde and an amine exhibiting the R2 group, followed by an alkylation of the secondary amine, leading to the compounds 29 and $\mathbf{3 0}$. Yields and chemical, physical and spectroscopic characteristics of $\mathbf{1}$ and its 31 analogues are reported in the Experimental section and in Supporting Information.

10

Biology. The FRET-based assay was a measurement of fluorescence emission of EGFP as a function of time at $510 \mathrm{~nm} \cdot{ }^{4,6-8}$ It proceeds through three different phases (Figure 1) and allows to determine if a non fluorescent molecule behaves as a competitor of the fluorescent molecule or if it rather mdodulates the interaction of the fluorescent molecule with the receptor. The phase P1 corresponds to the real time recording of the association of fluorescent NKA-Bo $(20 \mathrm{nM})$ to EGFP-labelled NK2 receptor. The observed decrease of EGFP fluorescence emission at $510 \mathrm{~nm}$ reflects energy transfer from excited EGFP (linked to the receptor) to the fluorophore bodipy (linked to neurokinin A) that develops over time. The phase P2 corresponds to the incubation period with the compound $(10 \mu \mathrm{M})$ to be tested. If the test compound is a competitor of NKA-Bo, an upward deflection is detected. This reflects partial-to-total dissociation of NKA-Bo from its binding site and consequent reduction of energy transfer. Alternatively, the compound may either not bind to the receptor or may behave as an allosteric modulator. It this case no signal would be detected during phase P2. The final phase, P3, corresponds to NKA-Bo dissociation from NK2-EGFP receptor following addition of $20 \mu \mathrm{M}$ of unlabeled NKA. During this phase, each NKA-Bo molecule that dissociates from its binding site is replaced by an unlabelled NKA molecule present in large excess. The rate of NKA dissociation, determined from the fitting of phase P3 
1 dissociation trace, is thus directly linked to the dissociation constant of NKA-Bo for a given 2 conformation of the NK2 receptor. In previous studies, ${ }^{6,8}$ fluorescent NKA was shown to dissociate 3 from two conformations of the NK2 receptor, the relative abundance of which depended on the 4 incubation time or on the pharmacological agent added to the preparation. A rapid dissociation rate 5 associated to a low affinity conformation characterized as a calcium signaling state was identified, 6 together with a slow dissociation rate corresponding to a high affinity cAMP-signaling state. In the 7 present work, dissociation traces are fitted using this two state model with the equation: $\mathrm{F}(\mathrm{t})=\lambda 1(\mathrm{k} 1 \mathrm{x}$ $8 \mathrm{t})+\lambda 2(\mathrm{k} 2 \mathrm{xt})$, where $\mathrm{F}(\mathrm{t})$ is the variation of fluorescence over time, $\lambda 1$ and $\lambda 2$ were the amplitudes of 9 the rapid and slow dissociation processes characterized by rate constants $\mathrm{k} 1$ and $\mathrm{k} 2$, respectively.

10 Best fits of dissociation traces were obtained according to Maillet et al. ${ }^{8}$ with two exponential 11 relaxations. The relative amplitudes $\lambda 1$ and $\lambda 2$ for rapid and slow dissociations were fitted using the 12 least square method and assigned to the corresponding conformations denominated A1 (for rapidly 13 dissociating, calcium signaling) and A2 (for slowly dissociating, cAMP-signaling), depending on the 14 compound present. When test compounds did not exhibit a competitive character (all but compounds 11, $1530,31,32$ ) determination of relative $\mathrm{A} 1$ and $\mathrm{A} 2$ abundances did not require rapid and slow rate 16 constants to be fixed. For compounds 11, 30, 31, 32, the residual amplitude of dissociation in the 17 presence of NKA was reduced and rate constant determinations were less precise. For the sake of 18 homogeneity, all data are presented here with imposed rate constants equal to $0.03 \mathrm{sec}^{-1}$ for rapid 19 dissociation, and $0.006 \mathrm{sec}^{-1}$ for slow dissociation. When excess of known competitive ligands such as 20 unlabeled NKA or the competitive NK2 receptor antagonist SR 48968 were used as competitors, 21 dissociation of NKA-Bo followed a bi-exponential time course with a rapid dissociation rate $(\mathrm{k} 1=0.03$ $\left.22 \mathrm{sec}^{-1}\right)$ accounting for $70 \%$ of the signal and a slow dissociation rate $\left(\mathrm{k} 2=0.006 \mathrm{sec}^{-1}\right)$ accounting for $2330 \%$ of the signal amplitude, resulting in a 30/70 ratio A1/A2 conformations as described in Maillet et $24 \mathrm{al}^{8}$ 
Results and discussion. The FRET-based screening at $10 \mu \mathrm{M}$ concentration of 1,600 compounds from our laboratory collection on the NK2-EGFP receptor led to the discovery of compound 1 (Chart 1). This hit was unable to fully reverse the binding of NKA-Bo alone but in the presence of an excess of 4 NKA, compound 1 significantly accelerated the dissociation kinetics of NKA-Bo (Table 1), showed no effect on (or weak potentiation of) the calcium-induced pathway (Figure 2) and dramatically inhibited NKA-induced cAMP response of the receptor (Figure 3). Because the dissociation rate of an orthosteric ligand can only be modified by a ligand able to bind simultaneously to the receptor, and therefore, on a topographically different binding site than the orthosteric ligand, the phenomenon of allosteric interaction between compound 1 with NKA-Bo to the neurokinin NK2 receptor was validated and confirms the existence of a $<$ NKA-compound 1-NK2 receptor $>$ ternary complex. Analysis of association kinetics of NKA revealed that $\mathbf{1}$ does not alter the affinity of the agonist for the different receptor conformations but rather prevents the formation of the 'cAMP-triggering conformation' while not affecting the formation of 'calcium-triggering conformation' of the NKA-NK2R complex. ${ }^{8}$ Compound 1 was thus identified as the first allosteric modulator of the neurokinin 2 receptor that discriminates among biologically active conformations of the receptor and exerts a selective, allosteric functional switch of a GPCR upon endogeneous ligand activation. Our aim here was to explore structural elements of the structure of 1 that determine its potential to increase the population of A1 conformation at a 10 $\mu \mathrm{M}$ concentration of allosteric ligand.

We attempted to modify the structure of $\mathbf{1}$ to obtain analogs with as low as possible competitive character and as high as possible modulating properties. Compounds are validated, using the FRETbased assay, by i) a lack of inhibition of NKA-Bo binding following the addition of the test compound and ii) an increase in the fraction of receptors inducing calcium production, and further characterized in functional assays. In this study, we report the structure and the allosteric activity of 31 analogues of $\mathbf{1}$. Their ability to induce an inhibition of FRET by themselves or to affect NKA-Bo dissociation kinetics at $10 \mu \mathrm{M}$ was analyzed. Most compounds interact with the NK2R. With the exception of compounds $\mathbf{5}, \mathbf{1 1}$,

30, 31 and $\mathbf{3 2}$ which could not be assigned as competitive agents or as negative allosteric effectors of 
NKA-Bo binding, all other ligands behave as non competitive, allosteric switches favoring the NKA-Bo induced calcium signaling states at the expense of the NKA-induced cAMP signaling (Tables 2, 3 and

3 4). We first modified the benzyl substituent (R1) of 1 (Chart 1 and Table 2). An introduction of a halogen atom on the benzyl ring either in position 4 or 2 , such as in compounds $\mathbf{2}, \mathbf{3}$, and $\mathbf{4}$, lead to a non significant reduction in the allosteric activity of the ligands (3-5\% reduction of A1 conformation). Another modification spacing the aromatic ring from the central nitrogen atom such as replacement of the benzyl by a phenethyl group in analog $\mathbf{5}$, did not improve the efficacy of the allosteric ligand. In contrast, introduction of an electron donor group, such as a 4-methoxy-benzyl in $\mathbf{6}$, seemed to lead to a slightly better efficacy (54\% of A1 conformation). If the substitution of the benzyl domain by halogen atoms had a slightly negative effect on the allosteric activity of the compounds, substitution with an electron donor group weakly reinforced the allosteric activity, but overall, the substitution of the benzyl group did not have a significant impact on the modulation of allosteric activity.

The importance of the naphthalen-2-ylmethyl moiety (Ar) of molecule 1 was then explored (Table 3). Its replacement by halogeno-benzyl groups, such as in compounds $\mathbf{7}$ and $\mathbf{8}$, had little influence on the allosteric activity (44 to $53 \%$ of A1 conformation). Replacement with an indol (analogue 9) resulted in a cytotoxic compound which could not be studied further. The quinolinyl group in $\mathbf{1 0}$ and $\mathbf{1 1}$, which could be viewed as hydrogen bond acceptor, did not lead to compounds better than $\mathbf{1}$. However, it is noteworthy that among the quinolinyl analogues, the quinolin-3-ylmethyl one (11) promoted a strong inhibition of FRET, supporting a competitive binding in addition to allosteric modulation, while the quinolin-2-ylmethyl one (10) conserved a pure non-competitive allosteric behavior.

In order to probe the importance of the rigidity of the bicycle in $\mathbf{1}$, the cinnamyl analogue $\mathbf{1 2}$ was synthesized. This compound exhibited an allosteric activity quite similar to 1 (47\% of A1 conformation). Interestingly, replacement of the naphthalen-2-ylmethyl moiety with a benzyl group substituted by an electron donating $-\mathrm{OMe}(\mathbf{1 3})$ or an electron withdrawing $-\mathrm{CF}_{3}$ group (14) had no effect on the activity of the ligands. Taken together, these results indicate that replacing the naphthalen2-ylmethyl group by diverse aromatic moieties did not increase significantly the allosteric modulator 
activity. This suggests that the Ar group located near the tertiary amine does not make strong specific interactions with the receptor and is most probably involved in the establishment of aromatic-aromatic interactions between the allosteric ligand and the allosteric site of the receptor.

The contribution of the acetonitrile substituent (R2) of the central nitrogen was then investigated (Table 4). The carbonitrile was first replaced by an alkyne group (compound 15). This compound showed an allosteric activity corresponding to $51 \% \mathrm{~A} 1$ conformation, thus equally active to compound 1, suggesting that the nitrile was not involved in any hydrogen bond but rather acted as an electron rich, polarisable moiety. The location of the nitrile was then explored in preparing compound $\mathbf{1 6}$ which is the superior homolog of $\mathbf{1}$. Interestingly, the allosteric activity was significantly improved up to $68 \%$ A1 conformation, suggesting the creation or the re-enforcement of an interaction between the nitrile function and the allosteric site. To further explore the carbonitrile modifications, an ester or an acid function was introduced in $\mathbf{1 7}$ or $\mathbf{1 8}$, respectively. The ethyl ester $\mathbf{1 7}$ retained a good allosteric activity (51\% of A1 conformation), as efficient as $\mathbf{1}$, without promoting an inhibition of FRET. In contrast, the corresponding acid derivative $\mathbf{1 8}$ lost some of its allosteric activity with promoting only $35 \%$ of A1 conformation. The elongation of the chain to four methylene groups (compounds $\mathbf{1 9}$ and $\mathbf{2 0}$ ) afforded an equi-active ester and an acid with some rescued allosteric activity (52\% and $44 \%$ of A1 conformation, respectively). The influence of the ester was then further explored with some derivatives such as compounds $\mathbf{2 1}$ to $\mathbf{2 4}$. Alkyl or aromatic hydrophobic esters $\mathbf{2 1}$ and $\mathbf{2 2}$ showed decreased activity. A short hydrophilic hydroxyethyl chain provided compound $\mathbf{2 3}$ as active as $\mathbf{1}$. The more bulky and basic chain, as found in $\mathbf{2 4}$, slightly decreased the allosteric activity to $42 \%$ of A1 conformation. Amides were then logically synthesized and tested. Four compounds, $\mathbf{2 5}$ to $\mathbf{2 8}$ were prepared. The N-butylamide $\mathbf{2 5}$ was as active as $\mathbf{1}$ but the cyclic piperidino analogue $\mathbf{2 6}$ was significantly less active than $\mathbf{1}$, with $44 \%$ of A1 conformation. The N'-methylpiperazin, $\mathrm{N}$-acetamide 27 was more active than 1 promoting $58 \%$ of A1 conformation, while the N'-phenyl derivative $\mathbf{2 8}$ was much less active than $\mathbf{1}$, suggesting a positive contribution of the additional N' basic atom, possibly related to its basicity. 
In a final round of chemical modifications, we replaced the carbonitrile function with electron-rich heteroaromatic groups. Compounds 29 to $\mathbf{3 2}$ were synthesized. They all exhibited an allosteric modulator activity superior to $\mathbf{1}$, but most of them (30-32) developed a significant inhibition of FRET intensity, supporting the notion that some competition with NKA may also be occurring.

Taken all together, the results obtained in the present study correspond to an improvement in term of allosteric activity supporting the calcium-induced pathway. However, the structure-activity relationship appears difficult to analyze since the allosteric activity remained very mildly sensitive to very diverse structural modifications. This led us to suggest that the interaction with the binding site might not involve very strong, oriented and specific bonds such as H-bonds but rather a set of diffuse hydrophobic, aromatic interactions with the allosteric site of the NK2 receptor. In order to find a possible explanation for these results we examined the three-dimensional model of the NK2 receptor derived from the bovine opsin crystal structure. ${ }^{10}$ To be consistent with our structure-activity relationship data we looked for aromatic domains accessible to ligands. Only two domains could clearly be identified (Figure 4). The first one was located at the entrance of the binding cleft, at the top of transmembrane domains TM1 and TM2 which corresponds to the cluster of three aromatic amino acids, Trp37(1.35), Tyr41(1.39) and Tyr93(2.64) (in green in the left panel, Figure 4). This pocket could be located in the direct neighborhood of the agonist binding site, ${ }^{11,12}$ which could account for an inhibition of FRET by exerting competitive interaction with the orthosteric ligand and could support the hypothesis of a competitive component of our ligands. Interestingly, a second aromatic cluster has been found at the top of transmembrane helices TM2 and TM3, pointing towards the outside of the helix bundle, that is toward the membrane (in blue in the right-hand panel, Figure 4). It encompassed five phenylalanine residues namely Phe85(2.56), 89(2.60), 105(3.24), 108(3.27) and 114(3.31). Such a cluster is unusual in GPCRs and could be on one hand, the binding site of compound $\mathbf{1}$, whereby promoting a conformational change in the receptor resulting in an increase of the calcium-induced pathway. Alternatively, it is now widely accepted that GPCRs exist and might function as dimers and allosteric ligands might modulate the homo 
1 or heterodimerization of GPCRs. ${ }^{13}$ A great number of GPCRs were shown to form homodimers or

2 multimers by Western blotting, by co-immuno-precipitation in transfected/infected cells or, more 3 recently, by "resonance energy transfer" techniques in transfected living cells (fluorescence and 4 bioluminescence resonance energy transfer: (FRET or BRET). ${ }^{14}$ Therefore, we suggest that these 5 phenylalanine residues could represent an attachment point between the protomers. The same cluster can 6 be found in homology models of NK2-R derived from the most recently published crystallographic 7 structures of the adrenergic and adenosine receptors. ${ }^{15-17}$ Thus, one may hypothesize that compound 1 8 may bind this aromatic bud and thereby either reinforce or disrupt the ability of protomers to dimerize,

9 resulting in conformational and functional switches. ${ }^{18}$ Though still speculative, the atypical features and

10 location of this aromatic cluster is worth mentioning to trigger experimental evaluation of its functional 11 relevance.

To summarize, only the modifications of the carbonitrile function of compound $\mathbf{1}$ were able to significantly increase the allosteric effect of the ligands, leading to an optimised hit, compound 16. Therefore, to further characterize the ability of compound $\mathbf{1 6}$ to increase the population of A1 conformation, intracellular calcium mobilization assays as well as cAMP accumulation were investigated at the NK2 receptor. Figure 2 shows that $\mathbf{1}$, as previously reported, ${ }^{8}$ did not modify the intracellular calcium response to a significant extent $\left(\mathrm{EC}_{50}=0.55 \pm 0.05 \mathrm{nM}\right.$ for $\mathrm{NKA}$ alone and $\mathrm{EC}_{50}=$ $0.50 \pm 0.05 \mathrm{nM}$ for NKA in presence of $20 \mu \mathrm{M}$ of $\mathbf{1})$. We note in this work that the $\mathrm{EC}_{50}$ values of NKA for calcium signaling, as well as for cAMP-signaling, are approximately 10-fold lower than those obtained previously. ${ }^{8}$ Consequently, inhibition of cAMP-responses by compound $\mathbf{1}$ looks less efficient. These changes are accounted for by inter-batches variations in surface expression of the EGFP-NK2 receptor as demonstrated by other groups. ${ }^{19,20}$ The activity of all compounds studied in the present work was evaluated in a newly selected cell line expressing EGFP-NK2R. Interestingly, compound $\mathbf{1 6}$ did not promote any drastic change in NKA potency $\left(\mathrm{EC}_{50}=0.62 \pm 0.04 \mathrm{nM}\right)$, but exhibited a significant increase of the agonist efficacy $($ Emax $=120 \pm 5 \%$ ), which reached a plateau approximately $20 \%$ higher than in control conditions, confirming that the butyronitrile group was definitely able to improve the 
1 biological activity of the modulator. Even more interestingly, in a cAMP accumulation assay (Figure 3),

compound 16 appeared more potent than compound 1, such that while compound $\mathbf{1}$ (as previously reported $^{8}$ ) was able to reduce the maximal effect of NKA of $33 \%$, compound $\mathbf{1 6}$ at an identical concentration, reduced the agonist efficacy of almost $50 \%$. These results suggest that, if compound 1 was exerting its allosteric effect unilaterally by only inhibiting the cAMP-induced response of NKA at the NK2 receptors while having no significant effect on the calcium response of the endogenous agonist, compound $\mathbf{1 6}$ is actually able to, on one hand potentiate the efficacy of NKA in calcium mobilization assay, while on the other hand, inhibit the efficacy of the endogenous agonist-induced cAMP response.

Allosteric modulation of GPCRs is now a well established concept, ${ }^{1,2,13,18,21,22,23}$ originally defined by the International Union of Pharmacology (IUPHAR: http://www.iuphar.org/) committee as 'modulators that enhance the affinity and/or efficacy of the orthosteric ligand while having no effect on their own'. ${ }^{24}$ Indeed many modulators that enhance or diminish the effects of agonists or antagonists on a variety of GPCRs are described, some of them reaching the clinical phase. ${ }^{21}$ On another hand, molecules have been described as being able to trigger on their own different signaling pathways upon binding to a given GPCR. ${ }^{25}$ This mechanism has been referred to as 'agonist-' or 'ligand-directed trafficking of receptor stimulus'. ${ }^{25-27}$ Compounds $\mathbf{1}$ and $\mathbf{1 6}$ open new perspectives since they combine both effects, allostery and stimulus trafficking: they have no effect on their own but they are able to traffic the stimulus of the endogenous ligand, NKA, from the cAMP to the Calcium signaling pathway. They are thus pure allosteric functional switches of the endogenous ligand. Such a pharmacological profile had been reported in 2006 for an ionic species, gadolinium $\left(\mathrm{Gd}^{3+}\right)$, acting at the class III metabotropic glutamate receptor $\mathrm{mGluR}_{1 \alpha}{ }^{28}$ To our knowledge, compound $\mathbf{1}$ was the first drug-like, allosteric switch of the function triggered by the endogenous ligand of a Class I GPCR ${ }^{8}$ A similar profile has been very recently considered for benzoylthiophenes modulating the function of a non-endogenous agonist of the A1 adenosine receptor. ${ }^{29}$ Compound $\mathbf{1 6}$ represents a relatively more potent allosteric modulator than $\mathbf{1}$ in the studied system. Its ability to switch the function of the endogenous ligand NKA in other cell types and in tissues relevant to human pathologies will have to be explored. However, the present results 
1 further illustrate the possibility to discover such molecules and pave the way for not only receptor-

2 selective but also signaling-pathway selective therapies under the physiological control of the 3 endogenous ligand release.

Conclusion. We have synthesized more than thirty compounds based on compound $\mathbf{1}$, an allosteric functional switch of a class I GPCR. Using a FRET based assay, we have characterized most of them as allosteric modulators of the NK2 receptor. These allosteric modulators exhibited the particularity of stabilizing the receptor in the calcium-triggering state (Gq coupling) to the detriment of the cAMP synthesizing state (Gs coupling). Our structure-activity relationship study led to the optimization of its allosteric activity, especially with the analogue $\mathbf{1 6}$ which enhanced the percentage of A1 conformation of NK2 receptor to $68 \%$ at $10 \mu \mathrm{M}$ and increased the function switch amplitude. We have now a new efficient allosteric modulator that can target specifically one among two signaling pathways activated by the endogenous ligand at a given receptor. This thus opens the road to a superior level of specificity for ligands acting at GPCRs, but their detailed mechanism of action as well as their functional and therapeutic potential remains to be explored.

\section{Experimental section}

\section{Chemistry.}

General. All chemicals used were of reagent grade. All commercialized compounds were purchased from Accros, Aldrich, Avocado, Fluka, Lancaster, and used without further purification. Progress of the reactions was monitored by TLC on silica gel plates. Extracts were dried over MgSO4, and solvents were removed under reduced pressure. Merck silica gel (Kieselgel 60) was used for flash chromatography (230-400 mesh) columns. Melting points were determined using a Mettler FP62 apparatus and are uncorrected. ${ }^{1} \mathrm{H}$ NMR and ${ }^{13} \mathrm{C}$ NMR spectra were recorded on Bruker DPX $200 \mathrm{MHz}$ and $300 \mathrm{MHz}$ spectrometers with TMS as internal standard; the values of the chemical shifts are given in ppm. Mass spectra were determined with a Perkin Elmer ESI-TOF apparatus (dilution of the product 
to a concentration of $10^{-6}$ in $\left.\mathrm{MeOH} / \mathrm{H} 2 \mathrm{O}=90 / 10\right)$. LC/MS spectra were obtained on a $\mathrm{ZQ}$ ( $\mathrm{Z}$ quadripole)

Waters/Micromass spectrometer equipped with an X-Terra C18 column $(4.6$ x $50 \mathrm{~mm}, 3.5 \mu \mathrm{m})$ using electrospray ionisation mode (ESI) with a linear gradient from water $(0.1 \% \mathrm{TFA})$ to $\mathrm{CH} 3 \mathrm{CN}(0.1 \%$ TFA). Retention times (Rt) from analytical RP-HPLC are reported in minutes. HRMS spectra were obtained on a MicroTof mass spectrometer from Bruker using electrospray ionisation (ESI) mode and a time-of-flight analyser (TOF). Elemental analyses were performed on a Perkin-Elmer 240C elemental analyzer, and the results are within $\pm 0.4 \%$ of the theoretical values. Yields refer to purified products and are not optimized. Purity of tested compounds was superior to $95 \%$ as ascertained by elementary analysis or LC-MS (see Experimental section and Supporting Information). The identity of the tested compounds was ascertained by ${ }^{1} \mathrm{H}$ NMR, ${ }^{13} \mathrm{NMR}$ and LC/MS (see Experimental section and Supporting Information).

General procedure for the synthesis of secondary amines. A mixture of aldehyde (1.0 eq) and substituted benzylamine $(1.0 \mathrm{eq})$ in $\mathrm{MeOH}(0.3 \mathrm{M})$ was first heated at $60{ }^{\circ} \mathrm{C}$ during $4 \mathrm{~h}$ and cooled at 0 ${ }^{\circ} \mathrm{C}$, NaBH4 (3 eq) was added to the reaction mixture and the solution was stirred for $4 \mathrm{~h}$ at $\mathrm{RT}$. After removal of the solvent, the solid residue obtained was dissolved in AcOEt. The organic layer was washed with a saturated solution of $\mathrm{NaHCO}_{3}$ (x2), water, saturated solution of $\mathrm{NaCl}$, then dried and reduced to yield an oil (40-99\%). The oil was used without further purification.

General procedure for the synthesis of tertiary amines. To a mixture of secondary amine (1.0 eq) and TEA (1.2 eq) in DMF (0.3 M) was added dropwise a solution of halogenated compound (1.1 eq) in DMF $(0.3 \mathrm{M})$. The solution was stirred overight at $60^{\circ} \mathrm{C}$ and the solvent was removed in vacuo. The resulting oil was dissolved in AcOEt; the organic layer was washed with a saturated solution of $\mathrm{NaHCO}_{3}(\mathrm{x} 2)$, water, saturated solution of $\mathrm{NaCl}$, then dried and reduced. The resulting product was purified by flash chromatography to yield an oil (32-98\%).

General procedure for the synthesis of amides. To a mixture of N,N-(2-naphthylmethyl-benzyl)-2aminoethanoic acid (1.0 eq) and N-methylmorpholine (3.2 eq) in DMF (0.3 M) was added a solution of substituted amine $(1.1 \mathrm{eq})$ in DMF $(0.3 \mathrm{M})$ followed by the coupling agent BOP. The solution was 
stirred for 1 night at RT and reduced. The resulting oil was dissolved in AcOEt; the organic layer was washed with water, with a saturated solution of $\mathrm{NaCl}$, dried and the solvent was removed in vacuo. The resulting product was purified by flash chromatography to yield the expected product $(67-96 \%)$.

General procedure for the synthesis of esters. To a mixture of N,N-(2-naphthylmethyl-benzyl)-2aminoethanoic acid (1.0 eq) and N-methylmorpholine (3.2 eq) in DMF (0.3M) was added a solution of substituted alcohol $(1.1 \mathrm{eq})$ in DMF $(0.3 \mathrm{M})$ followed by the coupling agent BOP. The solution was stirred overnight at RT and reduced. The resulting oil was dissolved in AcOEt; the organic layer was washed with water, a saturated solution of $\mathrm{NaCl}$, then dried and the solvent was removed in vacuo. The resulting product was purified by flash chromatography to yield the expected product $(35-84 \%)$.

General procedure for the synthesis of salts. $\mathrm{HCl}$ gas was bubbled for 2 minutes into a solution of basic compound $(0.3 \mathrm{M})$ in $\mathrm{Et}_{2} \mathrm{O}$ or AcOEt. After evaporation the resulting product was collected as an uncoloured powder.

(2-Naphthylmethyl)-benzylamine (a). Prepared from 2-naphtaldehyde (10 g, $64 \mathrm{mmol})$, benzylamine $(6.86 \mathrm{~g}, 64 \mathrm{mmol})$ and $\mathrm{NaBH}_{4}(7.3 \mathrm{~g}, 196 \mathrm{mmol})$ using the general procedure for the synthesis of secondary amines $(14.4 \mathrm{~g}, 91 \%) . \mathrm{Rf}=0.5(\mathrm{Hexane} / \mathrm{AcOEt}=2 / 1) .{ }^{1} \mathrm{H} \mathrm{NMR}\left(200 \mathrm{MHz}, \mathrm{CDCl}_{3}\right): \delta 7.89$ 7.82 (4H, m, H arom.), 7.55-7.28 (8H, m, H arom.), 4.02 (2H, s, - $\mathrm{CH}_{2}$-napht.), 3.89 (2H, s, - $\mathrm{CH}_{2}$-benz.).

2-Naphthylmethyl)-4-bromobenzylamine (b). Prepared from 2-naphtaldehyde (2.34 g, 15 mmol), 4bromobenzylamine $(2.79 \mathrm{~g}, 15 \mathrm{mmol})$ and $\mathrm{NaBH}_{4}(1.7 \mathrm{~g}, 45 \mathrm{mmol})$ using the general procedure for the synthesis of secondary amines (3.42 g, 70\%). Rf $=0.3\left(\right.$ Hexane/AcOEt=9/1). ${ }^{1} \mathrm{H}$ NMR $(200 \mathrm{MHz}$, $\left.\mathrm{CDCl}_{3}\right): \delta$ 7.85-7.81 (4H, m, $\mathrm{H}$ arom.), 7.49-7.44 (3H, m, $\mathrm{H}$ arom.), 7.29-7.28 (4H, m, H arom.), 3.96 (2H, s, - $\mathrm{CH}_{2}$-napht.), 3.80 (2H, s, - $\mathrm{CH}_{2}$-bromobenz.).

(2-Naphthylmethyl)-2-bromobenzylamine (c). Prepared from 2-naphtaldehyde (1.4 g, 9 mmol), 2bromobenzylamine $(1.67 \mathrm{~g}, 9 \mathrm{mmol})$ and $\mathrm{NaBH}_{4}(1 \mathrm{~g}, 27 \mathrm{mmol})$ using the general procedure for the synthesis of secondary amines (2.55 g, 87\%). Rf $=0.5$ (Hexane/AcOEt=2/1). ${ }^{1} \mathrm{H}$ NMR $(200 \mathrm{MHz}$, 
$\left.\mathrm{CDCl}_{3}\right): \delta$ 7.89-7.85 (4H, m, $\mathrm{H}$ arom.), 7.53-7.34 (5H, m, $\mathrm{H}$ arom.), 7.33-7.31 (1H, m, $\mathrm{H}$ arom.), 7.227.19 (1H, m, H arom.), 4.02 (2H, s, - $\mathrm{CH}_{2}$-napht.), 3.98 (2H, s, - $\mathrm{CH}_{2}$-benz.).

(2-Naphthylmethyl)-4-iodobenzylamine (d). Prepared from 2-naphtaldehyde (2 g, 12.8 mmol), 4iodobenzylamine $(2.98 \mathrm{~g}, 12.8 \mathrm{mmol})$ and $\mathrm{NaBH}_{4}(1.5 \mathrm{~g}, 38.4 \mathrm{mmol})$ using the general procedure for the synthesis of secondary amines (4.58 g, 96\%). Rf $=0.25(\mathrm{Hexane} / \mathrm{AcOEt}=9 / 1) .{ }^{1} \mathrm{H} \mathrm{NMR}(200 \mathrm{MHz}$, $\left.\mathrm{CDCl}_{3}\right): \delta$ 7.85-7.81 (5H, m, $\mathrm{H}$ arom.), 7.49-7.44 (4H, m, $\mathrm{H}$ arom.), 7.29-7.28 (2H, m, H arom.), 3.96 (2H, s, $-\mathrm{CH}_{2}$-napht.), 3.80 (2H, s, $-\mathrm{CH}_{2}$-iodobenz.).

(2-Naphthylmethyl)-4-phenethylbenzylamine (e). Prepared from 2-naphtaldehyde (73 mg, 0.46 mmol), 4-phenethylbenzylamine (100 mg, $0.46 \mathrm{mmol})$ and $\mathrm{NaBH}_{4}(50 \mathrm{mg}, 1.38 \mathrm{mmol})$ using the general procedure for the synthesis of secondary amines $(250 \mathrm{mg}, 99 \%)$. $\mathrm{Rf}=0.25$ (Hexane/AcOEt=8/2). ${ }^{1} \mathrm{H}$ NMR $\left(200 \mathrm{MHz}, \mathrm{CDCl}_{3}\right): \delta$ 7.80-7.78 (4H, m, H arom.), 7.51-7.46 (3H, m, H arom.), 7.30-7.18 (9H, m, H arom.), 3.98 (2H, s, - $\mathrm{CH}_{2}$-napht.), 3.83 (2H, s, - $\mathrm{CH}_{2}$-benz.), 2.93 (4H, s, $\mathrm{CH}_{2}-\mathrm{CH}_{2-}-$.

(2-Naphthylmethyl)-4-methoxybenzylamine (f). Prepared from 2-naphtaldehyde (500 mg, 3.2 mmol), 4-methoxybenzylamine (427 mg, $3.2 \mathrm{mmol})$ and $\mathrm{NaBH}_{4}(365 \mathrm{mg}, 9.6 \mathrm{mmol})$ using the general procedure for the synthesis of secondary amines $(736 \mathrm{mg}, 83 \%) . \mathrm{Rf}=0.35\left(\right.$ Hexane/AcOEt=9/1). ${ }^{1} \mathrm{H}$ NMR (200 MHz, $\mathrm{CDCl}_{3}$ ): $\delta$ 7.90-7.78 (4H, m, H arom.), 7.50-7.45 (3H, m, H arom.), 7.32-7.26 (2H, m, H arom.), 6.93-6.88 (2H, m, H arom.), 3.98 (2H, s, - $\mathrm{CH}_{2}$-napht.), 3.83 (5H, s, - $\mathrm{CH}_{2}$-methoxybenz.).

(3-Chlorobenzyl)-benzylamine (g). Prepared from 3-chlorobenzaldehyde (1 g, 7.1 mmol), benzylamine $(760 \mathrm{mg}, 7.1 \mathrm{mmol})$ and $\mathrm{NaBH}_{4}(810 \mathrm{mg}, 21.3 \mathrm{mmol})$ using the general procedure for the synthesis of secondary amines $(1.48 \mathrm{~g}, 90 \%) . \mathrm{Rf}=0.25(\mathrm{Hexane} / \mathrm{AcOEt}=9 / 1) .{ }^{1} \mathrm{H} \mathrm{NMR}(300 \mathrm{MHz}$, $\left.\mathrm{CDCl}_{3}\right): \delta$ 7.78-7.72 (4H, m, H arom.), 7.49-7.43 (5H, m, H arom.), 4.32 (2H, s, - $\mathrm{CH}_{2}$-chlorobenz.), 4.29 (2H, s, - $\mathrm{CH}_{2}$-benz.).

(4-Chlorobenzyl)-benzylamine (h). Prepared from 4-chlorobenzaldehyde (703 mg, 5 mmol), benzylamine $(535 \mathrm{mg}, 5 \mathrm{mmol})$ and $\mathrm{NaBH}_{4}(570 \mathrm{mg}, 15 \mathrm{mmol})$ using the general procedure for the 
1 synthesis of secondary amines (1.48 g, 90\%). Rf $=0.45$ (Hexane/AcOEt=7/3). ${ }^{1} \mathrm{H}$ NMR $(200 \mathrm{MHz}$,

$\left.2 \mathrm{CDCl}_{3}\right): \delta$ 7.36-7.33 (4H, m, $\mathrm{H}$ arom.); 7.32-7.30 (5H, m, H arom.); 3.81 (2H, s, - $\mathrm{CH}_{2}$-chlorobenz.);

$33.79\left(2 \mathrm{H}, \mathrm{s},-\mathrm{CH}_{2}\right.$-benz.).

N-(1H-Indol-3-ylmethyl)-N-benzylamine (i). Prepared from indol-3-carboxaldehyde (725 mg, 5

$5 \mathrm{mmol})$, benzylamine $(540 \mathrm{mg}, 5 \mathrm{mmol})$ and $\mathrm{NaBH}_{4}(570 \mathrm{mg}, 15 \mathrm{mmol})$ using the general procedure for

6 the synthesis of secondary amines $(0.62 \mathrm{~g}, 52 \%) . \mathrm{Rf}=0.85(\mathrm{AcOEt}) .{ }^{1} \mathrm{H} \mathrm{NMR}\left(300 \mathrm{MHz}, \mathrm{CDCl}_{3}\right): \delta$

7 7.91-7.72 (4H, m, H arom.), 7.61-7.49 (4H, m, H arom.), 7.33 (1H, t, J = 7.2 Hz, H arom.), 7.20 (1H, t, J

$8=7.2 \mathrm{~Hz}, \mathrm{H}$ arom.), 4.01 (2H, s, $-\mathrm{CH}_{2}$-indol.), 3.98 (2H, s, $-\mathrm{CH}_{2}$-benz.).

9 N-(quinol-2-ylmethyl)-N-benzylamine (j). Prepared from quinolin-2-carboxaldehyde (500 mg, 3.2 $10 \mathrm{mmol}$ ), benzylamine (340 mg, $3.2 \mathrm{mmol})$ and $\mathrm{NaBH}_{4}(365 \mathrm{mg}, 9.6 \mathrm{mmol})$ using the general procedure 11 for the synthesis of secondary amines $(0.64 \mathrm{~g}, 80 \%)$. Rf $=0.25\left(\right.$ Hexane/AcOEt:=5/5). ${ }^{1} \mathrm{H}$ NMR $(300$ $\left.12 \mathrm{MHz}, \mathrm{CDCl}_{3}\right): \delta$ 7.86-7.79 (2H, m, $\mathrm{H}$ arom.), 7.74-7.73 (1H, d, $\mathrm{H}$ arom.), 7.65-7.60 (1H, m, $\mathrm{H}$ arom.), 13 7.45-7.30 (7H, m, H arom.), 4.10 (2H, s, - $\mathrm{CH}_{2}$-quinol.), 3.85 (2H, s, - $\mathrm{CH}_{2}$-benz.).

N-(quinol-3-ylmethyl)-N-benzylamine (k). Prepared from quinolin-3-carboxaldehyde (500 mg, 3.2

$15 \mathrm{mmol}$ ), benzylamine (340 mg, $3.2 \mathrm{mmol})$ and $\mathrm{NaBH}_{4}(365 \mathrm{mg}, 9.6 \mathrm{mmol})$ using the general procedure for the synthesis of secondary amine $(0.75 \mathrm{~g}, 95 \%) . \mathrm{Rf}=0.25(\mathrm{Hexane} / \mathrm{AcOEt}=5 / 5) .{ }^{1} \mathrm{H}$ NMR $(300$ $\mathrm{MHz}, \mathrm{CDCl}_{3}$ ): $\delta 8.90$ (1H, s, $\mathrm{H}$ arom.), 8.12-8.08 (2H, m, H arom.), 7.81-7.79 (1H, m, H arom.), 7.797.77 (1H, m, H arom.), 7.71-7.69 (1H, m, H arom.), 7.37-7.27 (5H, m, H arom.), 4.00 (2H, s, $-\mathrm{CH}_{2}-$ quinol.), 3.87 (2H, s, - $\mathrm{CH}_{2}$-benz.).

N-(4-Trifluoromethylbenzyl)-benzylamine (1). Prepared from 4-trifluorobenzaldehyde (500 mg, 2.9 mmol), benzylamine $(310 \mathrm{mg}, 2.9 \mathrm{mmol})$ and $\mathrm{NaBH}_{4}(330 \mathrm{mg}, 8.7 \mathrm{mmol})$ using the general procedure for the synthesis of secondary amines $(0.65 \mathrm{~g}, 85 \%)$. Rf $=0.3$ (Hexane/AcOEt=9/1). ${ }^{1} \mathrm{H}$ NMR $(300$ $\left.\mathrm{MHz}, \mathrm{CDCl}_{3}\right): \delta$ 7.63-7.60 (2H, d, J= $9 \mathrm{~Hz}, \mathrm{H}$ arom.), 7.51-7.48 (2H, d, J=8.3 Hz, H arom.), 7.36-7.30 (5H, m, H arom.), 3.89 (2H, s, - $\mathrm{CH}_{2}$-trifluorobenz.), 3.84 (2H, s, $-\mathrm{CH}_{2}$-benz.). 
N-(4-Methoxybenzyl)-benzylamine (m). Prepared from 4-methoxybenzaldehyde (500 mg, 3.7

mmol), benzylamine (393 mg, $3.7 \mathrm{mmol})$ and $\mathrm{NaBH}_{4}(420 \mathrm{mg}, 11.1 \mathrm{mmol})$ using the general procedure for the synthesis of secondary amines $(0.65 \mathrm{~g}, 77 \%)$. Rf $=0.3$ (Hexane/AcOEt=9/1). 1H NMR (300 $\mathrm{MHz}, \mathrm{CDCl} 3): \delta$ 7.39-7.31 (7H, m, H arom.), 6.92-6.89 (2H, m, H arom.), $3.82\left(3 \mathrm{H}, \mathrm{s},-\mathrm{CH}_{3}\right), 3.75(2 \mathrm{H}$, s, - $\mathrm{CH}_{2}$-methoxybenz.), 3.70 (2H, s, - $\mathrm{CH}_{2}$-benz.).

(2E)-N-Benzyl-3-phenylprop-2-en-amine (n). Prepared from trans-cinnamaldehyde (660 mg, 5 mmol), benzylamine (535 mg, $5 \mathrm{mmol})$ and $\mathrm{NaBH}_{4}(570 \mathrm{mg}, 15 \mathrm{mmol})$ using the general procedure for the synthesis of secondary amines $(0.90 \mathrm{~g}, 81 \%) . \mathrm{Rf}=0.35(\mathrm{Hexane} / \mathrm{AcOEt}=8 / 2) .{ }^{1} \mathrm{H} \mathrm{NMR}(300 \mathrm{MHz}$, $\left.\mathrm{CDCl}_{3}\right): \delta$ 7.42-7.25 (10H, m, H arom.), 7.60-7.55 (1H, d, J= 15 Hz, H arom.), 6.40-6.30 (1H, m, -CH-), 3.88 (2H, s, - $\mathrm{CH}_{2}$-benz.), 3.48-3.46 (2H, d, J=6Hz, $-\mathrm{CH}_{2}$-cinn.).

N-(2-Naphthylmethyl)-3-aminopyridine (o). To a solution of 2-naphtaldehyde (1eq, $500 \mathrm{mg}$, $3.2 \mathrm{mmol})$ and 3-aminopyridine (1 eq, $300 \mathrm{mg}, 3.2 \mathrm{mmol})$ in ethanol $(0,3 \mathrm{M})$ heated at $95{ }^{\circ} \mathrm{C}$ during $48 \mathrm{~h}$ then cooled to $0{ }^{\circ} \mathrm{C}, \mathrm{NaBH}_{4}(3 \mathrm{eq}, 380 \mathrm{mg}, 10 \mathrm{mmol}$ ) was added. The solution was stirred overnight at RT and reduced. The resulting oil was dissolved in AcOEt; the organic layer was washed with a solution of $\mathrm{NaOH} 1 \mathrm{~N}(\mathrm{x} 2)$, water, saturated solution of $\mathrm{NaCl}$, then dried and reduced. The resulting product was purified by flash chromatography with AcOEt/Hexane (75/25) to yield an oil $(300 \mathrm{mg}, 40 \%)$. Rf $=0.3$ (Hexane/AcOEt=1/9). ${ }^{1} \mathrm{H}$ NMR (300 MHz, $\left.\mathrm{CDCl}_{3}\right): \delta$ 8.15-8.11 (1H, d, H arom.), 7.97-7.94 (1H, m, H arom.), 7.92-7.69 (4H, m, H arom.), 7.49-7.41 (3H, m, H arom.), 7.10-7.02 (1H, m, H arom.), 6.94-6.88 (1H, m, H arom.), 4.54-4.51 (2H, d, J=8.9Hz, $-\mathrm{CH}_{2}$-napht.).

N-(2-Naphthylmethyl)-2-aminomethylpyridine (p). Prepared from 2-naphtaldehyde (500 mg, 3.2 mmol), 2-aminomethylpyridine (350 mg, $3.2 \mathrm{mmol})$ and $\mathrm{NaBH}_{4}(380 \mathrm{mg}, 10 \mathrm{mmol})$ using the general procedure for the synthesis of secondary amines $(550 \mathrm{mg}, 70 \%)$. The resulting oil was purified by flash chromatography with AcOEt/Hexane/TEA (9/1/2\%). Rf $=0,15$ (Hexane/AcOEt/TEA=1/9/2\%). ${ }^{1} \mathrm{H}$ NMR (300 MHz, $\mathrm{CDCl}_{3}$ ): $\delta$ 8.11-8.09 (1H, d, H arom.), 7.91-7.87 (4H, m, H arom.), 7.65-7.62 (1H, t, J $=4.2 \mathrm{~Hz}, \mathrm{H}$ arom.), 7.54-7.44 (3H, m, H arom.), 7.34-7.31 (1H, d, J = 7.8 Hz, H arom.), 7.19-7.15 (1H, m, $\mathrm{H}$ arom.), 4.03 (2H, s, - $\mathrm{CH}_{2}$-pyr.), 3.98 (2H, s, $-\mathrm{CH}_{2}$-napht.). 
[N-Benzyl,N-(2-naphthylmethyl)-amino]-acetonitrile (1). Prepared from the secondary amine a

2 (1.24 g, $5 \mathrm{mmol})$, chloroacetonitrile $(415 \mathrm{mg}, 5.5 \mathrm{mmol})$ and TEA $(610 \mathrm{mg}, 6 \mathrm{mmol})$ using the general

3 procedure for the synthesis of tertiary amines. The resulting product was purified in isopropyl alcohol to

4 yield a white solid $(1.2 \mathrm{~g}, 84 \%) . \mathrm{Rf}=0.3(\mathrm{Hexane} / \mathrm{AcOEt}=9 / 1) .{ }^{1} \mathrm{H} \mathrm{NMR}\left(300 \mathrm{MHz}, \mathrm{CDCl}_{3}\right): \delta 7.90-$

57.80 (4H, m, H arom.), 7.60-7.20 (8H, m, H arom.), 3.92 (2H, s, $-\mathrm{CH}_{2}$-napht.), 3.81 (2H, s, $-\mathrm{CH}_{2}$-benz.),

$63.40\left(2 \mathrm{H}, \mathrm{s},-\mathrm{CH}_{2}-\mathrm{CN}\right) .{ }^{13} \mathrm{C}$ NMR (50 MHz, DMSO-d6): $\delta 136.58,134.80,132.34,132.20,131.52$,

$7130.87,130.68,113.81,60.12,59.20,41.22 . \mathrm{Mp}=92{ }^{\circ} \mathrm{C}$; Anal. $(\mathrm{C}, \mathrm{H}, \mathrm{N}) \mathrm{C}=83.75 \% . \mathrm{H}=6.28 \%, \mathrm{~N}=$

$8 \quad 9.77 \% . \mathrm{HRMS} \mathrm{m} / \mathrm{z}(\mathrm{M}+\mathrm{H})^{+} 287.1538$

9 [4-Bromobenzyl-(2-naphthylmethyl)-amino]-acetonitrile (2). Prepared from the secondary amine b 10 (3.42 g, $10.5 \mathrm{mmol})$, chloroacetonitrile $(875 \mathrm{mg}, 11.6 \mathrm{mmol})$ and TEA (1.27 $\mathrm{g}, 12.6 \mathrm{mmol})$ using the 11 general procedure for the synthesis of tertiary amines. The resulting product was purified by 12 crystallization $(2.37 \mathrm{~g}, 65 \%) . \mathrm{Rf}=0,15$ (Hexane/AcOEt=9/1). ${ }^{1} \mathrm{H}$ NMR $\left(200 \mathrm{MHz}, \mathrm{CDCl}_{3}\right): \delta 7.90-7.85$ 13 (4H, m, H arom.), 7.55-7.51 (4H, m, H arom.), 7.36-7.30 (3H, m, H arom.), 3.92 (2H, s, - $\mathrm{CH}_{2}$-napht.), 143.78 (2H, s, - $\mathrm{CH}_{2}$-benz.), $3.42\left(2 \mathrm{H}, \mathrm{s},-\mathrm{CH}_{2}-\mathrm{CN}\right) .{ }^{13} \mathrm{C}$ NMR (50 MHz, DMSO-d6): $\delta$ 136.57, 134.74, $15133.70,133.49,132.26,131.01,129.01,128.37,128.22,127.03,126.77,126.56,122.15,58.84,58.08$, 16 41.27. $\mathrm{Mp}=110^{\circ} \mathrm{C}$. Anal. $(\mathrm{C}, \mathrm{H}, \mathrm{N}) \mathrm{C}=66.01 \%, \mathrm{H}=4.67 \%, \mathrm{~N}=7.61 \% . \mathrm{HRMS} \mathrm{m} / \mathrm{z}(\mathrm{M}+\mathrm{H})^{+} 366.0648$.

[2-Bromobenzyl-(2-naphthylmethyl)-amino]-acetonitrile (3). Prepared from the secondary amine c 18 (2.55 g, $7.8 \mathrm{mmol})$, chloroacetonitrile $(648 \mathrm{mg}, 8.6 \mathrm{mmol})$ and TEA (945 $\mathrm{mg}, 9.36 \mathrm{mmol})$ using the 19 general procedure for the synthesis of tertiary amines. The resulting product was purified by flash chromatography with Hexane/AcOEt=9/1 to yield a white solid $(1,7 \mathrm{~g}, 60 \%) . \quad \mathrm{Rf}=0.9$ 21 (Hexane/AcOEt=2/1). ${ }^{1} \mathrm{H}$ NMR $\left(200 \mathrm{MHz}, \mathrm{CDCl}_{3}\right): \delta 7.88-7.84(3 \mathrm{H}, \mathrm{m}, \mathrm{H}$ arom.), 7.68-7.50 (4H, m, H arom.), 7.41-7.18 (4H, m, H arom.), 3.99 (2H, s, - $\mathrm{CH}_{2}$-napht.), 3.97 (2H, s, - $\mathrm{CH}_{2}$-bromobenz.), 3.41 $\left(2 \mathrm{H}, \mathrm{s},-\mathrm{CH}_{2}-\mathrm{CN}\right) .{ }^{13} \mathrm{C}$ NMR (75 MHz, DMSO-d6): $\delta$ 132.91, 131.80, 129.5, 127.72, 127.0, 126.49, 126.32, 58.76, 57.97, 41.45. $\mathrm{Mp}=71{ }^{\circ} \mathrm{C}$. Anal. $(\mathrm{C}, \mathrm{H}, \mathrm{N}) \mathrm{C}=63.0 \%, \mathrm{H}=4.72 \%, \mathrm{~N}=7.22 \%, 1 \mathrm{H} 2 \mathrm{O}$. 
[4-Iodobenzyl-(2-naphthylmethyl)-amino]-acetonitrile (4). Prepared from the secondary amine d

2 (4.83 g, $12.8 \mathrm{mmol})$, chloroacetonitrile $(982 \mathrm{mg}, 13 \mathrm{mmol})$ and TEA (1.31 g, $13 \mathrm{mmol})$ using the 3 general procedure for tertiary amines. The resulting product was purified by flash chromatography with Hexane/AcOEt=95/5 to yield a white solid (3.65 g, 69\%). Rf =0.25 (Hexane/AcOEt=95/5). ${ }^{1} \mathrm{H}$ NMR (200 MHz, $\left.\mathrm{CDCl}_{3}\right): \delta$ 7.90-7.85 (4H, m, H arom.), 7.55-7.51 (4H, m, H arom.), 7.36-7.30 (3H, m, H 6 arom.), $3.92\left(2 \mathrm{H}, \mathrm{s},-\mathrm{CH}_{2}\right.$-napht.), 3.78 (2H, s, $-\mathrm{CH}_{2}$-iodobenz.), $3.42\left(2 \mathrm{H}, \mathrm{s},-\mathrm{CH}_{2}-\mathrm{CN}\right) .{ }^{13} \mathrm{C}$ NMR $(75$ MHz, DMSO-d6): $\delta 137.66,135.27,133.23,132.88,131.33,128.57,127.90,127.63,127.02,126.59$, $126.32,115.78,93.85,57.75,57.09,41.50 . \mathrm{Mp}=116^{\circ} \mathrm{C} . \mathrm{HRMS} \mathrm{m} / \mathrm{z}(\mathrm{M}+\mathrm{H})^{+} 413.0509$.

[4-Phenethylbenzyl-(2-naphthylmethyl)-amino]-acetonitrile (5). Prepared from the secondary amine e (200 mg, $0.57 \mathrm{mmol})$, chloroacetonitrile (43 mg, $0.57 \mathrm{mmol})$ and TEA (57 $\mathrm{mg}, 0.57 \mathrm{mmol})$ using the general procedure for the tertiary amine. The resulting product was purified by flash chromatography with Hexane/AcOEt=95/5 to yield a white solid (195 mg, 87\%). Rf $=0.15$ (Heptane/AcOEt=95/5). ${ }^{1} \mathrm{H}$ NMR (300 MHz, $\left.\mathrm{CDCl}_{3}\right): \delta$ 7.91-7.87 (4H, m, H arom.), 7.60-7.51 (3H, m, H arom.), 7.40-7.20 (9H, m, H arom.), 3.94 (2H, s, - $\mathrm{CH}_{2}$-napht.), 3.81 (2H, s, - $\mathrm{CH}_{2}$-benz.), 3.43 (2H,s, $\left.\mathrm{CH}_{2}-\mathrm{CN}\right), 2.96\left(4 \mathrm{H}, \mathrm{s},-\mathrm{CH}_{2}-\mathrm{CH}_{2}-\right) .{ }^{13} \mathrm{C} \mathrm{NMR}\left(75 \mathrm{MHz}, \mathrm{CDCl}_{3}\right): \delta 141.94,140.90,136.57,133.02$, 131.47, 130.97, 128.54, 125.01, 119.78, 113.82, 63.31, 45.83, 37.44. HRMS m/z (M+H) 391.47

[4-Methoxybenzyl-(2-naphthylmethyl)-amino]-acetonitrile (6). Prepared from the secondary amine f (720 mg, $2.6 \mathrm{mmol})$, chloroacetonitrile $(212 \mathrm{mg}, 2.8 \mathrm{mmol})$ and TEA (323 mg, $3.2 \mathrm{mmol})$ using the general procedure for tertiary amines. The resulting product was purified by flash chromatography with Hexane/AcOEt=95/5 to yield a white solid (595 mg, 60\%). Rf $=0.45\left(\right.$ Hexane/AcOEt=8/2). ${ }^{1} \mathrm{H}$ NMR arom.), 3.89 (2H, s, - $\mathrm{CH}_{2}$-napht.), 3.82 (3H, s, $\left.-\mathrm{CH}_{3}\right), 3.74$ (2H, s, $-\mathrm{CH}_{2}$-benz.), 3.38 (2H, s, $\left.-\mathrm{CH}_{2}-\mathrm{CN}\right)$. ${ }^{13} \mathrm{C}$ NMR (50 MHz, DMSO-d6): $\delta$ 154.44, 129.86, 128.47, 128.20, 125.40, 124.22, 123.65, 123.03, 122.97, 122.86, 121.97, 121.43, 121.20, 109.88, 109.21, 53.50, 52.95, 50.46, 35.77. $\mathrm{Mp}=86^{\circ} \mathrm{C}$. Anal. $(\mathrm{C}, \mathrm{H}, \mathrm{N}) \mathrm{C}=79.45 \%, \mathrm{H}=6.54 \%, \mathrm{~N}=8.74 \% . \mathrm{HRMS} \mathrm{m} / \mathrm{z}(\mathrm{M}+\mathrm{H})^{+} 317.1648$. 
[Benzyl-(3-chlorobenzyl)-amino]-acetonitrile hydrochloride (7). Prepared from the secondary

amine $\mathbf{g}(1.50 \mathrm{~g}, 6.40 \mathrm{mmol})$, chloroacetonitrile $(530 \mathrm{mg}, 7.0 \mathrm{mmol})$ and TEA (775 $\mathrm{mg}, 7.7 \mathrm{mmol})$ using the general procedure for the synthesis of tertiary amines. The resulting product was purified by flash chromatography with Hexane/AcOEt=95/5 to yield a white solid $(805 \mathrm{mg}, 41 \%)$. $\mathrm{Rf}=0.3$ (Hexane/AcOEt=95/5). ${ }^{1} \mathrm{H} \mathrm{NMR}\left(300 \mathrm{MHz}, \mathrm{CDCl}_{3}\right): \delta$ 7.81-7.78 (4H, m, H arom.), 7.51-7.46 (5H, m, $\mathrm{H}$ arom.), 4.30 (2H, s, - $\mathrm{CH}_{2}$-chlorobenz.), 4.27 (2H, s, $-\mathrm{CH}_{2}$-benz.), $3.75\left(2 \mathrm{H}, \mathrm{s},-\mathrm{CH}_{2}-\mathrm{CN}\right) .{ }^{13} \mathrm{C}$ NMR (50 MHz, DMSO-d6): $\delta$ 137.54, 135.03, 133.71, 133.46, 129.41, 129.10, 128.92, 128.25, 128.10, $127.14,126.70,126.46,115.08,58.87,58.82,41.22$. Synthesis of the salt. Mp $=120{ }^{\circ} \mathrm{C}$. Anal. $(\mathrm{C}, \mathrm{H}, \mathrm{N})$ $\mathrm{C}=62.40 \%, \mathrm{H}=5.47 \%, \mathrm{~N}=8.14 \% 1 \mathrm{HCl} . \mathrm{HRMS} \mathrm{m} / \mathrm{z}(\mathrm{M}+\mathrm{H})^{+} 271.1002$.

[Benzyl-(4-chlorobenzyl)-amino]-acetonitrile hydrochloride (8). Prepared from the secondary amine h (1.05 g, $4.5 \mathrm{mmol}$ ), chloroacetonitrile (375 mg, $4.95 \mathrm{mmol})$ and TEA (545 mg, $5.4 \mathrm{mmol})$ using the general procedure for the synthesis of tertiary amines. The resulting product was purified by flash chromatography with Hexane/AcOEt $=95 / 5$ to yield a white solid $(580 \mathrm{mg}, 42 \%)$. $\mathrm{Rf}=0.3$ (Hexane/AcOEt=95/5). ${ }^{1} \mathrm{H} \mathrm{NMR}\left(300 \mathrm{MHz}, \mathrm{CDCl}_{3}\right): \delta$ 7.79-7.76 (4H, m, H arom.), 7.50-7.45 (5H, m, $\mathrm{H}$ arom.), 4.32 (2H, s, - $\mathrm{CH}_{2}$-chlorobenz.), 4.28 (2H, s, $-\mathrm{CH}_{2}$-benz.), $3.73\left(2 \mathrm{H}, \mathrm{s},-\mathrm{CH}_{2}-\mathrm{CN}\right) .{ }^{13} \mathrm{C} \mathrm{NMR}$ (75 MHz, DMSO-d6): $\delta 136.95,136.17,132.58,131.00,129.20,128.92,128.89,128.09,115.51,57.52$, 56.76, 41.25. $\mathrm{Mp}=124{ }^{\circ} \mathrm{C}$. Anal. $(\mathrm{C}, \mathrm{H}, \mathrm{N}) \mathrm{C}=62.83 \%, \mathrm{H}=5.24 \%, \mathrm{~N}=9.12 \%, 1 \mathrm{HCl} . \mathrm{HRMS} \mathrm{m} / \mathrm{z}$ $(\mathrm{M}+\mathrm{H})^{+} 271.0984$.

[Benzyl-(1H-indol-3-ylmethyl)-amino]-actonitrile hydrochloride (9). Prepared from the secondary amine i (613 mg, $2.6 \mathrm{mmol})$, chloroacetonitrile (216 mg, $2.85 \mathrm{mmol})$ and TEA (315 g, $3.12 \mathrm{mmol})$ using the general procedure for the synthesis of tertiary amines. The resulting product was purified by flash chromatography with Hexane/AcOEt=2/1 to yield a white solid $(640 \mathrm{mg}, 80 \%) . \mathrm{Rf}=0.75$ (Hexane/AcOEt=2/1). ${ }^{1} \mathrm{H}$ NMR $(300 \mathrm{MHz}, \mathrm{CDCl} 3): \delta$ 7.81-7.76 $(1 \mathrm{H}, \mathrm{d}, \mathrm{J}=5 \mathrm{~Hz}, \mathrm{H}$ arom.), 7.45-7.30 (7H, m, H arom.), 7.25-7.16 (2H, m, H arom.), 3.97 (2H, s, $-\mathrm{CH}_{2}$-indol.), 3.82 (2H, s, - $\mathrm{CH}_{2}$-benz.), 3.39 $\left(2 \mathrm{H}, \mathrm{s},-\mathrm{CH}_{2}-\mathrm{CN}\right) .{ }^{13} \mathrm{C}$ NMR (75 MHz, DMSO-d6): $\delta 139.41,137.12,131.94,131.13,129.54,128.07$, 
$123.60,122.47,120.23,119.48,114.75,112.18,102.21,50.74,50.06,34.06$. Synthesis of the salt. Mp $=$ $150{ }^{\circ} \mathrm{C}$. Anal. $(\mathrm{C}, \mathrm{H}, \mathrm{N}) \mathrm{C}=68.71 \%, \mathrm{H}=5.81 \%, \mathrm{~N}=13.49 \%, 1 \mathrm{HCl} . \mathrm{HRMS} \mathrm{m} / \mathrm{z}(\mathrm{M}+\mathrm{H})^{+} 276.5005$.

[Benzyl-(quinolin-2-ylmethyl)-amino]-acetonitrile dihydrochloride (10). Prepared from the secondary amine $\mathbf{j}$ (635 mg, $2.56 \mathrm{mmol})$, chloroacetonitrile (212 mg, $2.81 \mathrm{mmol})$ and TEA (310 g, 3.07 mmol) using the general procedure for the synthesis of tertiary amines. The resulting product was purified by flash chromatography with Hexane/AcOEt=8/2 to afford a yellow solid $(690 \mathrm{mg}, 75 \%) . \mathrm{Rf}=$ $0.2\left(\right.$ Hexane/AcOEt=8/2). ${ }^{1} \mathrm{H}$ NMR $\left(300 \mathrm{MHz}, \mathrm{CDCl}_{3}\right): \delta$ 7.85-7.83 (1H, d, H arom.), 7.82-7.80 (1H, d, H arom.), 7.74-7.72 (1H, d, H arom.), 7.63-7.56 (1H, d, H arom.), 7.44-7.37 (2H, m, H arom.), 7.357.31 (5H, m, H arom.), 4.11 (2H, s, - $\mathrm{CH}_{2}$-quinol.), 3.83 (2H, s, - $\mathrm{CH}_{2}$-benz.), 3.55 (2H, s, $\left.-\mathrm{CH}_{2}-\mathrm{CN}\right) .{ }^{13} \mathrm{C}$ NMR (75 MHz, DMSO-d6): $\delta$ 157.79, 144.34, 140.06, 136.94, 133.69, 129.35, 128.82, 128.06, 127.93, $122.65,122.13,116.13,58.35,56.28,42.72$. Synthesis of the salt. $\mathrm{Mp}=160{ }^{\circ} \mathrm{C}$. Anal. $(\mathrm{C}, \mathrm{H}, \mathrm{N}) \mathrm{C}=$ $63.53 \%, \mathrm{H}=5.35 \%, \mathrm{~N}=11.59 \%, 2 \mathrm{HCl}$. HRMS m/z $(\mathrm{M}+\mathrm{H})^{+} 288.1488$.

[Benzyl-(quinolin-3-ylmethyl)-amino]-acetonitrile dihydrochloride (11). Prepared from the secondary amine $\mathbf{k}(635 \mathrm{mg}, 2.56 \mathrm{mmol})$, chloroacetonitrile $(210 \mathrm{mg}, 2.80 \mathrm{mmol})$ and TEA (310 g, 3.07 mmol) using the general procedure for the synthesis of tertiary amine. The resulting product was purified by flash chromatography with Hexane/AcOEt=7/3 to yield a yellow solid $(505 \mathrm{mg}, 55 \%) . \mathrm{Rf}=$ 0.3 (Hexane/AcOEt=7/3). ${ }^{1} \mathrm{H}$ NMR (300 MHz, $\left.\mathrm{CDCl}_{3}\right): \delta 7.83-7.81(1 \mathrm{H}, \mathrm{d}, \mathrm{H}$ arom.), 7.84-7.81 (1H, d, H arom.), 7.75-7.73 (1H, d, H arom.), 7.63-7.55 (1H, d, H arom.), 7.44-7.37 (2H, m, H arom.), 7.357.29 (5H, m, H arom.), 4.10 (2H, s, - $\mathrm{CH}_{2}$-quinol.), 3.85 (2H, s, $-\mathrm{CH}_{2}$-benz.), 3.57 (2H, s, $-\mathrm{CH}_{2}$ - $\left.\mathrm{CN}\right) .{ }^{13} \mathrm{C}$ NMR (75 MHz, DMSO-d6): $\delta$ 148.51, 140.33, 138.15, 133.92, 131.45, 130.97, 126.71, 124.61, 123.64, $123.19,117.92,61.54,57.96,44.64$. Synthesis of the salt. $\mathrm{Mp}=190{ }^{\circ} \mathrm{C}$. Anal. $(\mathrm{C}, \mathrm{H}, \mathrm{N}) \mathrm{C}=63.54 \%, \mathrm{H}=$ $5.36 \%, \mathrm{~N}=11.79 \%, 2 \mathrm{HCl} . \mathrm{HRMS} \mathrm{m} / \mathrm{z}(\mathrm{M}+\mathrm{H})+288.1509$.

\{Benzyl-[(2E)-3-phenylprop-2-en-1-yl]-amino\}-acetonitrile hydrochloride (12). Prepared from the secondary amine $\mathbf{n}(903 \mathrm{mg}, 4.05 \mathrm{mmol})$, chloroacetonitrile (336 mg, $445 \mathrm{mmol})$ and TEA (490 g, 4,85 mmol) using the general procedure for the synthesis of tertiary amines. The resulting product was purified by flash chromatography with Hexane/AcOEt=9/1 to yield a yellow solid $(556 \mathrm{mg}, 46 \%) . \mathrm{Rf}=$ 
0,3 (Hexane/AcOEt=9/1). ${ }^{1} \mathrm{H}$ NMR (200 MHz, $\left.\mathrm{CDCl}_{3}\right): \delta=7.49-7.28$ (10H, m, H arom.), 6.73-6.65 $\left(1 \mathrm{H}, \mathrm{d}, \mathrm{J}=16 \mathrm{~Hz}, \mathrm{H}\right.$ arom.), 6.29-6.14 (1H, m, -CH-), $3.75\left(2 \mathrm{H}, \mathrm{s},-\mathrm{CH}_{2}\right.$-benz. $), 3.51$ (2H, s, $-\mathrm{CH}_{2}-$ cinn.), 3.43-3.39 (2H, d, J = 6.8 Hz, $\left.-\mathrm{CH}_{2}-\mathrm{CN}\right) .{ }^{13} \mathrm{C}$ NMR (75 MHz, DMSO-d6): $\delta \square=136.28,136.16$, $134.23,130.26,129.03,128.98,128.48,127.00,122.40,114.79,57.31,55.68,41.58$. Synthesis of the salt. $\mathrm{Mp}=170{ }^{\circ} \mathrm{C}$. Anal. $(\mathrm{C}, \mathrm{H}, \mathrm{N}) \mathrm{C}=71.96 \%, \mathrm{H}=6.49 \%, \mathrm{~N}=9.18 \%, 1 \mathrm{HCl} . \mathrm{HRMS} \mathrm{m} / \mathrm{z}(\mathrm{M}+\mathrm{H})^{+}$ 263.1544.

[Benzyl-(4-methoxybenzyl)-amino]-acetonitrile hydrochloride (13). Prepared from the secondary amine $\mathbf{m}$ (635 mg, $2.85 \mathrm{mmol})$, chloroacetonitrile (237 mg, $3.14 \mathrm{mmol})$ and TEA (345 mg, $3.42 \mathrm{mmol})$ using the general procedure for the synthesis of tertiary amines. The resulting product was purified by flash chromatography with Hexane/AcOEt=97/3 to yield a white solid (485 mg, 56\%). Rf $=0.2$ (Hexane/AcOEt=97/3). ${ }^{1} \mathrm{H}$ NMR (300 MHz, CDCl3): $\delta$ 7.39-7.31 (7H, m, H arom.), 6.92-6.89 (2H, m, H arom.), 3.82 (3H, s, -CH3), 3.74 (2H, s, -CH2-methoxybenz.), 3.70 (2H, s, -CH2-benz.), 3.37 (2H, s, CH2-CN). ${ }^{13} \mathrm{C}$ NMR (50 MHz, DMSO-d6): $\delta$ 161.54, 133.27, 131.68, 130.86, 130.01, 128.85, 120.43, $115.30,111.65,58.54,58.45,55.81,38.75$. Synthesis of the salt. $\mathrm{Mp}=114{ }^{\circ} \mathrm{C} . \mathrm{HRMS} \mathrm{m} / \mathrm{z}(\mathrm{M}+\mathrm{H})^{+}$ 267.1485

\{Benzyl-[4-(trifluoromethyl)-benzyl]-amino\}-acetonitrile hydrochloride (14). Prepared from the secondary amine I (660 mg, $2.5 \mathrm{mmol})$, chloroacetonitrile (210 mg, $2.75 \mathrm{mmol})$ and TEA (300 mg, 3 mmol) using the general procedure for the synthesis of tertiary amines. The resulting product was purified by flash chromatography with Hexane/AcOEt=97/3 to yield a white solid $(580 \mathrm{mg}, 68 \%) . \mathrm{Rf}=$ 0.3 (Hexane/AcOEt=97/3). ${ }^{1} \mathrm{H}$ NMR (300 MHz, CDCl3): $\delta$ 7.72-7.68 (2H, d, H arom.), 7.60-7.55 (2H, m, $\mathrm{H}$ arom.), 7.41-7.35 (5H, m, $\mathrm{H}$ arom.), 3.83 (2H, s, $-\mathrm{CH}_{2}$-trifluorobenz.), 3.78 (2H, s, - $\mathrm{CH}_{2}$-benz.), $3.41(2 \mathrm{H}, \mathrm{s},-\mathrm{CH} 2-\mathrm{CN}) .{ }^{13} \mathrm{C}$ NMR (75 MHz, DMSO-d6): $\delta 151.36,147.16,140.13,133.21,132.82$, $131.76,131.12,129.33,128.95,128.52,127.94,127.21,126.92,124.76,57.85,54.77$. Synthesis of the salt. HRMS m/z (M+H) 305.1261 . 
[Benzyl-(2-naphthylmethyl)-propargyl]-amine (15). Prepared from the secondary amine a (1.24 g,

$25 \mathrm{mmol})$, propargyl bromide $(655 \mathrm{mg}, 5.5 \mathrm{mmol})$ and TEA $(610 \mathrm{mg}, 6 \mathrm{mmol})$ using the general

3 procedure for the synthesis of tertiary amines. The resulting product was purified in isopropyl alcohol to

4 yield a white solid (1.29 g, 82\%). Rf $=0.3\left(\right.$ Hexane/AcOEt=9/1). ${ }^{1} \mathrm{H} \mathrm{NMR}\left(300 \mathrm{MHz}, \mathrm{CDCl}_{3}\right): \delta 7.90-$

57.80 (4H, m, H arom.), 7.60-7.20 (8H, m, H arom.), 3.93 (2H, s, $-\mathrm{CH}_{2}$-napht.), 3.82 (2H, s, $-\mathrm{CH}_{2}$-benz.),

$63.34\left(2 \mathrm{H}, \mathrm{s},-\mathrm{CH}_{2}-\mathrm{CN}\right) .{ }^{13} \mathrm{C}$ NMR (50 MHz, DMSO-d6): $\delta$ 136.58, 134.80, 132.34, 132.20, 131.52,

$7130.87,130.68,113.81,60.12,59.20,41.22 . \mathrm{Mp}=92{ }^{\circ} \mathrm{C}$. Anal. $(\mathrm{C}, \mathrm{H}, \mathrm{N}) \mathrm{C}=88.40 \%, \mathrm{H}=6.68 \%, \mathrm{~N}=$

$8 \quad 4.98 \%$. HRMS m/z (M+H) 286.1538.

9 4-[Benzyl-(2-naphthylmethyl)-amino]-butyronitrile hydrochloride (16). Prepared from the 10 secondary amine a (500 mg, $2.5 \mathrm{mmol})$, 4-bromobutyronitrile (410 mg, $2.75 \mathrm{mmol})$ and TEA (303 mg, 3 $11 \mathrm{mmol}$ ) using the general procedure for tertiary amines. The resulting product was purified by flash 12 chromatography with Hexane/AcOEt $=95 / 5$ to yield a yellow solid $(550 \mathrm{mg}, 63 \%) . \mathrm{Rf}=0.2$ 13 (Hexane/AcOEt=9/1). ${ }^{1} \mathrm{H}$ NMR $\left(300 \mathrm{MHz}, \mathrm{CDCl}_{3}\right): \delta$ 7.90-7.81 (3H, m, H arom.), $7.75(1 \mathrm{H}, \mathrm{s}, \mathrm{H}$ 14 arom.), 7.49-7.46 (3H, m, $\mathrm{H}$ arom.), 7.37-7.35 (5H, m, $\mathrm{H}$ arom.), 3.73 (2H, s, $-\mathrm{CH}_{2}$-napht.), 3.63 (2H, s, 15 -CH2-benz.), $2.60\left(2 \mathrm{H}, \mathrm{t}, \mathrm{J}=6.4 \mathrm{~Hz},-\mathrm{CH}_{2}-\mathrm{N}\right), 2.32\left(2 \mathrm{H}, \mathrm{t}, \mathrm{J}=7.5 \mathrm{~Hz},-\mathrm{CH}_{2}-\mathrm{CN}\right), 1.85-1.81(2 \mathrm{H}, \mathrm{m},-$ $\left.\mathrm{CH}_{2}-\mathrm{CH}_{2}-\mathrm{CH}_{2}-\mathrm{CN}\right) .{ }^{13} \mathrm{C}$ NMR (50 MHz, DMSO-d6): $\delta 133.38,132.88,131.88,131.69,130.16,129.83$, $129.83,129.16,128.75,128.57,128.44,128.00,127.67,127.44,127.02,119.91,56.55,50.13,19.62$, 14.25. Synthesis of the salt. Anal. $(\mathrm{C}, \mathrm{H}, \mathrm{N}) \mathrm{C}=71.46 \%, \mathrm{H}=6.70 \%, \mathrm{~N}=7.47 \%, 1 \mathrm{HCl}, 1 \mathrm{H} 2 \mathrm{O} . \mathrm{HRMS} \mathrm{m} / \mathrm{z}$ $19(\mathrm{M}+\mathrm{H})^{+} 315.1850$.

N-Ethyl-[benzyl-(2-naphthylmethyl)-amine] acetate (17). Prepared from the secondary amine a (800 mg, $4 \mathrm{mmol})$, 2-bromoethylacetate $(740 \mathrm{mg}, 4.5 \mathrm{mmol})$ and TEA (505 $\mathrm{mg}, 5 \mathrm{mmol})$ using the general procedure for tertiary amines. The resulting product was purified by flash chromatography with Hexane/AcOEt=95/5 to yield a white solid $(1.12 \mathrm{~g}, 84 \%) . \mathrm{Rf}=0.25(\mathrm{Hexane} / \mathrm{AcOEt}=95 / 5) .{ }^{1} \mathrm{H}$ NMR (200 MHz, $\left.\mathrm{CDCl}_{3}\right): \delta$ 7.90-7.78 (4H, m, H arom.), 7.60-7.55 (1H, d, H arom.), 7.48-7.66 (7H, m, H arom.), 4.18-4.14 (2H, q, $\left.-\mathrm{CH}_{2}-\mathrm{CH}_{3}\right), 3.98$ (2H, s, $-\mathrm{CH}_{2}$-napht.), 3.87 (2H, s, $-\mathrm{CH}_{2}$-benz.), 3.32 (2H, s, - 
$\left.\mathrm{CH}_{2}-\mathrm{CN}\right), 1.27\left(3 \mathrm{H}, \mathrm{t}, \mathrm{J}=4.5 \mathrm{~Hz},-\mathrm{CH}_{3}\right) .{ }^{13} \mathrm{C} \mathrm{NMR}(50 \mathrm{MHz}, \mathrm{DMSO}-\mathrm{d} 6): \delta 170.89,139.13,136.92$, $133.26,132.76,128.98,127.89,127.87,127.38,126.39,126.01,60.10,57.58,57.36,53.54,14.44 . \mathrm{Mp}$ $=69^{\circ} \mathrm{C}$. Anal. $(\mathrm{CHN}) \mathrm{C}=71.46 \%, \mathrm{H}=6.70 \%, \mathrm{~N}=3.47 \%, \mathrm{HCl} . \mathrm{HRMS} \mathrm{m} / \mathrm{z}(\mathrm{M}+\mathrm{H})^{+} 334.1802$.

[Benzyl-(2-naphthylmethyl)-amino]-acetic acid (18). Prepared from the tertiary amine 17 (400 mg, $1.7 \mathrm{mmol})$ and $\mathrm{HCl} 6 \mathrm{~N}(12 \mathrm{~mL})$ heated at $100^{\circ} \mathrm{C}$ over night. The solution was cooled and the precipitate was filtered then washed with few $\mathrm{mL}$ of diethylether to yield a white solid (510 mg, 98\%). ${ }^{1} \mathrm{H} \mathrm{NMR}$ (300 MHz, DMSO-d6): $\delta 8.05$ (1H, s, H arom.), 7.98-7.92 (3H, m, H arom.), 7.72-7.68 (1H, d, H arom.), 7.58-7.54 (4H, m, H arom.), 7.43-7.40 (3H, m, H arom.), 4.49 (2H, s, - $\left.\mathrm{CH}_{2}-\mathrm{COOH}\right), 4.38$ (2H, s, - $\mathrm{CH}_{2}$-napht.), 3.76 (2H, s, - $\mathrm{CH}_{2}$-benz.). ${ }^{13} \mathrm{C}$ NMR (50 MHz, DMSO-d6): $\delta$ 170.21, 134.97, 133.34, 132.98, 131.91, 130.91, 129.74, 129.27, 128.55, 121.13, 60.37, 60.09, 52.91. Mp $=154{ }^{\circ} \mathrm{C}$. Anal. $(\mathrm{C}, \mathrm{H}, \mathrm{N}) \mathrm{C}=79.32 \%, \mathrm{H}=6.99 \%, \mathrm{~N}=4.19 \%$. HRMS m/z $(\mathrm{M}+\mathrm{H})^{+} 306.1489$.

Ethyl 5-[Benzyl-(2-naphthylmethyl)-amino]-pentanoate (19). Prepared from the secondary amine a (1 g, $4 \mathrm{mmol})$, 5-bromoethylvalerate $(836 \mathrm{mg}, 4 \mathrm{mmol})$ and TEA ( $808 \mathrm{mg}, 8 \mathrm{mmol})$. The resulting product was purified by flash chromatography with Hexane/AcOEt=95/5 to yield a white solid ( $1.07 \mathrm{~g}$, 70\%). Rf = $0.15\left(\right.$ Heptane/AcOEt=95/5). ${ }^{1} \mathrm{H}$ NMR $\left(200 \mathrm{MHz}, \mathrm{CDCl}_{3}\right): \delta 7.89-7.77(4 \mathrm{H}, \mathrm{m}, \mathrm{H}$ arom. $)$, 7.48-7.32 (8H, m, H arom.), 4.19-4.05 (2H, m, - $\mathrm{CH}_{2}$-napht.), 3.71 (2H, s, - $\mathrm{CH}_{2}$-benz.), 3.60 (2H, s, $\left.\mathrm{CH}_{2}-\mathrm{CH}_{2}-\mathrm{CH}_{2}-\mathrm{CH}_{2}-\mathrm{COOEt}\right), 2.51-2.45$ (2H, m, $\left.-\mathrm{CH}_{2}-\mathrm{COOEt}\right), 2.37-2.30\left(2 \mathrm{H}, \mathrm{m},-\mathrm{CH}_{2}-\mathrm{CH}_{3}\right), 1.62-$ $1.58\left(4 \mathrm{H}, \mathrm{m},-\mathrm{CH}_{2}-\mathrm{CH}_{2}-\mathrm{CH}_{2}-\mathrm{CH}_{2}-\mathrm{COOEt}\right), 1.30-1.24\left(3 \mathrm{H}, \mathrm{m},-\mathrm{CH}_{3}\right) .{ }^{13} \mathrm{C} \mathrm{NMR}(50 \mathrm{MHz}, \mathrm{DMSO}-\mathrm{d} 6): \delta$ $174.32,133.28,132.92,131.78,130.32,129.79,128.54,127.97,127.42,127.00,56.31,50.98,45.63$, 31.04, 22.35, 8.74. $\mathrm{Mp}=126^{\circ} \mathrm{C} . \mathrm{MS} \mathrm{m} / \mathrm{z}(\mathrm{M}+\mathrm{H})^{+} 376.16$.

5-[benzyl2-naphthylmethyl)-amino]-pentanoic acid hydrochloride (20). A solution of tertiary amine $18(100 \mathrm{mg}, 0.27 \mathrm{mmol})$ in $\mathrm{HCl} 6 \mathrm{~N}(12 \mathrm{~mL})$ was heated overnight at $100{ }^{\circ} \mathrm{C}$ and then cooled at 0 ${ }^{\circ} \mathrm{C}$. The precipitate was filtered and suspended in diethylether to yield a white solid (105 mg,100\%). ${ }^{1} \mathrm{H}$ NMR (300 MHz, DMSO-d6): $\delta$ 8.16-7.84 (4H, m, H arom.), 7.67-7.58 (4H, m, H arom.), 7.45-7.39 (4H, m, H arom.), 4.20-4.15 (2H, m, - $\mathrm{CH}_{2}$-napht.), 3.81-3.79 (2H, m, $-\mathrm{CH}_{2}$-benz.), 3.70-3.68 (2H, m, $-\mathrm{CH}_{2}$ - 
$\left.\mathrm{CH}_{2}-\mathrm{CH}_{2}-\mathrm{CH}_{2}-\mathrm{COOH}\right), 2.51-2.45\left(2 \mathrm{H}, \mathrm{m},-\mathrm{CH}_{2}-\mathrm{COOH}\right), 1.62-1.58\left(4 \mathrm{H}, \mathrm{m},-\mathrm{CH}_{2}-\mathrm{CH}_{2}-\mathrm{CH}_{2}-\mathrm{CH}_{2}-\right.$

$2 \mathrm{COOH}) .{ }^{13} \mathrm{C}$ NMR (50 MHz, DMSO-d6): $\delta$ 174.30, 133.34, 132.87, 131.78, 131.59, 130.33, 129.79,

$3129.13,128.69,128.53,128.41,128.00,127.80,127.43,127.02,56.28,50.98,33.19,31.04,22.36$,

4 21.97. $\mathrm{Mp}=84^{\circ} \mathrm{C} . \mathrm{MS} \mathrm{m} / \mathrm{z}(\mathrm{M}+\mathrm{H})^{+} 348.06$.

5 [Benzyl-(2-naphthylmethyl)-amino]-hexadecanoyl acetate hydrochloride (21). Prepared from 1-

6 hexadecanol (187 mg, $0.77 \mathrm{mmol})$, acid 18 (200 mg, $0.65 \mathrm{mmol})$, BOP (345 mg, $0.78 \mathrm{mmol})$ and NMM

7 (303 mg, $3 \mathrm{mmol}$ ) in a solution of acetonitrile $5 \mathrm{~mL}$ and DMF $500 \mu \mathrm{L}$ using the general procedure for 8 the synthesis of esters. The resulting product was purified by flash chromatography with 9 Hexane/AcOEt=98/2 to yield an oil $(221 \mathrm{mg}, 60 \%) . \mathrm{Rf}=0.5($ Heptane/AcOEt: $95 / 5) .{ }^{1} \mathrm{H}$ NMR $(300$ $10 \mathrm{MHz}, \mathrm{CDCl} 3): \delta$ 7.89-7.75 (4H, m, H arom.), 7.51-7.32 (8H, m, H arom.), 4.17-4.11 (2H, t, J = $6 \mathrm{~Hz},-$ $11 \mathrm{CH}_{2}$-O-), 4.02 (2H, s, - $\mathrm{CH}_{2}$-napht.), 3.91 (2H, s, - $\mathrm{CH}_{2}$-benz.), 3.37 (2H, s, - $\left.\mathrm{CH}_{2}-\mathrm{CO}\right), 1.30(31 \mathrm{H}, \mathrm{m},-$ $\left.12\left(\mathrm{CH}_{2}\right)_{14}-\mathrm{CH}_{3}\right) .{ }^{13} \mathrm{C}$ NMR $(50 \mathrm{MHz}, \mathrm{CDCl} 3): \delta 166.39,134.18,133.42,132.12,130.65,129.95,129.41$, $13128.75,128.25,127.82,127.25,126.86,66.89,58.07,48.05,32.32,30.09,29.84,29.77,29.49,28.65$, $1426.06,23.03,14.53$. Synthesis of the salt. $\mathrm{Mp}=140{ }^{\circ} \mathrm{C}$. HRMS $\mathrm{m} / \mathrm{z}(\mathrm{M}+\mathrm{H})^{+} 530.3993$.

15 [Benzyl-(2-naphthylmethyl)-amino]-phenethyle acetate hydrochloride (22). Prepared from 16 phenethyl alcohol (81 mg, $0.77 \mathrm{mmol})$, acid 18 (200 mg, $0.65 \mathrm{mmol})$, BOP (345 mg, $0.78 \mathrm{mmol})$ and $17 \mathrm{NMM}(303 \mathrm{mg}, 3 \mathrm{mmol})$ in a solution of acetonitrile $5 \mathrm{~mL}$ and DMF $500 \mu \mathrm{L}$ using the general 18 procedure for the synthesis of esters. The resulting product was purified by flash chromatography with 19 Hexane/AcOEt=95/5 to yield a yellow hygroscopic powder $(198 \mathrm{mg}, 57 \%)$. $\mathrm{Rf}=0.25$ 20 (Heptane/AcOEt=95/5). ${ }^{1} \mathrm{H}$ NMR $\left(300 \mathrm{MHz}, \mathrm{CDCl}_{3}\right): \delta 7.79-7.74(3 \mathrm{H}, \mathrm{m}, \mathrm{H}$ arom.), $7.62(1 \mathrm{H}, \mathrm{s}, \mathrm{H}$ 21 arom.), 7.51-7.47 (2H, m, H arom.), 7.36-7.14 (11H, m, H arom.), 4.86 (2H, t, - $\left.\mathrm{CH}_{2}-\mathrm{O}-\right), 3.68$ (2H, s, $22 \mathrm{CH}_{2}$-napht.), 3.57 (2H, s, - $\mathrm{CH}_{2}$-benz.), 3.21 (2H, s, - $\mathrm{CH}_{2}$-CO-), 2.97 (2H, t, - $\mathrm{CH}_{2}$-Phen.). ${ }^{13} \mathrm{C}$ NMR (50 $\left.23 \mathrm{MHz}, \mathrm{CDCl}_{3}\right): \delta 166.17,136.96,134.20,133.43,132.32,132.16,130.69,129.86,129.24,129.13$, $24128.85,128.25,127.85,127.35,126.65,67.06,58.21,48.77,35.20$. HRMS m/z $(\mathrm{M}+\mathrm{H})^{+} 410.2115$. 
Methylsulfonyl 2-hydroxyethyle (q). In a solution of DCM (50 mL) with TEA (4,9 g, $48.3 \mathrm{mmol})$ and ethylene glycol (2 g, $32.3 \mathrm{mmol})$ was added mesyl chloride $(5.53 \mathrm{mg}, 48.03 \mathrm{mmol})$ at $0{ }^{\circ} \mathrm{C}$ during 3 $\mathrm{h}$, then stirred $2 \mathrm{~h}$ at RT. The resulting product was purified by flash chromatography with Hexane/AcOEt=25/75 to yield a colorless oil $(905 \mathrm{mg}, 20 \%) . \mathrm{Rf}=0.2\left(\right.$ Heptane/AcOEt=25/75). ${ }^{1} \mathrm{H}$ NMR (300 MHz, $\left.\mathrm{CDCl}_{3}\right): \delta 4.37-4.34\left(2 \mathrm{H}, \mathrm{m},-\mathrm{CH}_{2}-\mathrm{O}-\mathrm{SO}_{2}\right), 3.92-3.89\left(2 \mathrm{H}, \mathrm{m},-\mathrm{CH}_{2}-\mathrm{OH}\right), 3.09(3 \mathrm{H}, \mathrm{s}$, $\left.-\mathrm{CH}_{3}\right), 2.20(1 \mathrm{H}, \mathrm{s},-\mathrm{OH})$.

Methylsulfonyl ethyl-[benzyl-(2-naphthylmethyl)-amino]-2-acetate (r). To a solution of acid 18 (200 mg, $0.65 \mathrm{mmol}$ ) in acetonitrile $5 \mathrm{~mL}$ and DMF 500 $\mu \mathrm{L}$ was added NMM (303 mg, $3 \mathrm{mmol}$ ), BOP

9 (292 mg, $0.66 \mathrm{mmol})$ and ethylene glycol monomesyle (100 mg, $0.7 \mathrm{mmol})$. The mixture was stirred at RT overnight. The resulting product was purified by flash chromatography with Hexane/AcOEt (from 9/1 to $7 / 3)$ to yield a white oil $(98 \mathrm{mg}, 35 \%) . \mathrm{Rf}=0.4\left(\right.$ Heptane/AcOEt=25/75). ${ }^{1} \mathrm{H} \mathrm{NMR}(300 \mathrm{MHz}$,

4.33 (4H, m, - $\left.\mathrm{CH}_{2}-\mathrm{CH}_{2}-\right), 3.98$ (2H, s, - $\mathrm{CH}_{2}$-napht.), 3.87 (2H, s, - $\mathrm{CH}_{2}$-benz.), 3.39 (2H, s, - $\left.\mathrm{CH}_{2}-\mathrm{CO}\right)$, $2.93\left(3 \mathrm{H}, \mathrm{s},-\mathrm{CH}_{3}\right)$.

[Benzyl-(2-naphthylmethyl)-amino]-2-hydroxyethyl acetate (23). The mesyl r (100 mg, 0.23 mmol) was dissolved in toluene $10 \mathrm{~mL}$, then were added few $\mathrm{mg}$ of para-toluene sulfonic acid and the mixture was stirred at reflux during $16 \mathrm{~h}$. The resulting product was purified by flash chromatography with Hexane/AcOEt=8/2 to yield a yellow powder $(30 \mathrm{mg}, 35 \%) .{ }^{1} \mathrm{H} \mathrm{NMR}\left(300 \mathrm{MHz}, \mathrm{CDCl}_{3}\right): \delta 7.92-$ 7.79 (4H, m, H arom.), 7.63-7.57 (3H, m, H arom.), 7.45-7.28 (5H, m, H arom.), 4.38-4.33 (2H, m, $\mathrm{CH}_{2}$-OCO-), 4.15-4.10 (2H, m, - $\left.\mathrm{CH}_{2}-\mathrm{OH}\right), 3.98$ (2H, s, - $\mathrm{CH}_{2}$-napht.), 3.93 (2H, s, - $\mathrm{CH}_{2}$-benz.), 3.19 (2H, s, $\left.-\mathrm{CH}_{2}-\mathrm{CO}\right) .{ }^{13} \mathrm{C}$ NMR (50 MHz, DMSO-d6): $\delta 170.72,140.39,132.94,129.04,128.62,128.35$, $127.96,126.89,124.89,123.78,119.78,59.98,58.91,57.94,56.87 . \mathrm{MS} \mathrm{m} / \mathrm{z}(\mathrm{M}+\mathrm{H})^{+} 350.3$.

[Benzyl-(2-naphthylmethyl)-amino]-ethylmorpholine acetate hydrochloride (24). Prepared from 4-(2-hydroxyethyl)morpholine (101 mg, $0.77 \mathrm{mmol})$, acid 18 (200 mg, $0.65 \mathrm{mmol})$, BOP (345 mg, 0.78 mmol) and NMM (303 mg, $3 \mathrm{mmol})$ in a solution of acetonitrile $5 \mathrm{~mL}$ and THF $500 \mu \mathrm{L}$ using the general procedure for the synthesis of esters. The resulting product was purified by flash 
chromatography with Hexane/AcOEt (from $7 / 3$ to $5 / 5)$ to yield an oil $(118 \mathrm{mg}, 40 \%$ ). $\mathrm{Rf}=0.3$ (Heptane/AcOEt=7/3). ${ }^{1} \mathrm{H}$ NMR (300 MHz, $\left.\mathrm{CDCl}_{3}\right): \delta$ 7.89-7.79 (4H, m, H arom.), 7.65-7.60 (1H, m, H arom.), 7.47-7.30 (7H, m, H arom.), 4.30-4.26 (2H, t, J=4Hz, -O- $\left.\mathrm{CH}_{2}-\mathrm{CH}_{2}-\right), 4.01\left(2 \mathrm{H}, \mathrm{s},-\mathrm{CH}_{2}-\right.$ napht.), $3.90\left(2 \mathrm{H}, \mathrm{s},-\mathrm{CH}_{2}\right.$-benz.), 3.72-3.68 (4H, t, J = $\left.4 \mathrm{~Hz},-\mathrm{CH}_{2}-\mathrm{O}-\mathrm{CH}_{2}-\right), 3.38\left(2 \mathrm{H}, \mathrm{s},-\mathrm{CH}_{2}-\mathrm{CO}\right), 2.68-2.62$ $\left(2 \mathrm{H}, \mathrm{t}, \mathrm{J}=6 \mathrm{~Hz},-\mathrm{CH}_{2}-\mathrm{N}\right), 2.54-2.49\left(4 \mathrm{H}, \mathrm{m},-\mathrm{CH}_{2}-\mathrm{N}_{-} \mathrm{CH}_{2}-\right) .{ }^{13} \mathrm{C}$ NMR (50 MHz, DMSO-d6): $\delta$ 167.72, $133.43,132.85,131.84,131.67,130.41,129.92,129.15,128.73,128.47,128.01,127.47,127.03,63.40$, $58.52,57.73,55.27,51.78,50.92,31.06$. Synthesis of the salt. HRMS m/z $(\mathrm{M}+\mathrm{H})^{+} 419.2329$.

[Benzyl-(2-naphthylmethyl)-amino]-N-butyl-acetamide hydrochloride (25). Prepared from nbutylamine (45 mg, $0.62 \mathrm{mmol})$, acid 18 (200 mg, $0.59 \mathrm{mmol})$, BOP (273 mg, $0.62 \mathrm{mmol})$ and NMM (130 mg, $1.29 \mathrm{mmol})$ using the general procedure for the synthesis of amides. The resulting product was purified by flash chromatography with Hexane/AcOEt=7/3 to yield a white powder $(200 \mathrm{mg}, 85 \%)$. $\mathrm{Rf}=$ $0.2\left(\right.$ Hexane/AcOEt=7/3). ${ }^{1} \mathrm{H}$ NMR $\left(300 \mathrm{MHz}, \mathrm{CDCl}_{3}\right): \delta$ 7.91-7.88 (3H, m, H arom.), 7.75 (1H, s, H arom.), 7.38-7.36 (3H, m, H arom.), 7.35-7.30 (5H, m, H arom.), 3.79 (2H, s, - $\mathrm{CH}_{2}$-napht.), 3.69 (2H, s, - $\mathrm{CH}_{2}$-benz.), $3.18\left(2 \mathrm{H}, \mathrm{s},-\mathrm{CH}_{2}-\mathrm{CO}\right), 1.48-1.40\left(2 \mathrm{H}, \mathrm{m},-\mathrm{NH}-\mathrm{CH}_{2}-\right), 1.35-1.25\left(2 \mathrm{H}, \mathrm{m},-\mathrm{CH}_{2}-\mathrm{CH}_{2}-\mathrm{CH}_{2}-\right.$ $\left.\mathrm{CH}_{3}\right), 0.97-0.88\left(5 \mathrm{H}, \mathrm{m},-\mathrm{CH}_{2}-\mathrm{CH}_{3}\right) .{ }^{13} \mathrm{C} \mathrm{NMR}(50 \mathrm{MHz}, \mathrm{DMSO}-\mathrm{d} 6): \delta 165.76,135.72,134.91,133.37$, $132.95,131.85,130.85,130.63,129.77,129.27,129.08,128.48,128.04,60.91,60.75,53.29,40.59$, 32.45, 21.27, 14.31. Synthesis of the salt. $\mathrm{Mp}=160^{\circ} \mathrm{C} . \mathrm{HRMS} \mathrm{m} / \mathrm{z}(\mathrm{M}+\mathrm{H})^{+} 361.2274$.

[Benzyl-(2-naphthylmethyl)-amino]-piperidino-acetamide hydrochloride (26). Prepared from piperidine (52 mg, $0.62 \mathrm{mmol})$, acid 18 (200 mg, $0.59 \mathrm{mmol})$, BOP (273 mg, $0.62 \mathrm{mmol})$ and NMM $(130 \mathrm{mg}, 1.29 \mathrm{mmol})$ using the general procedure for the synthesis of amides. The resulting product was purified by flash chromatography with Hexane/AcOEt=8/2 to yield a white powder $(220 \mathrm{mg}, 91 \%) .{ }^{1} \mathrm{H}$ NMR (300 MHz, $\left.\mathrm{CDCl}_{3}\right): \delta$ 7.85-7.75 (4H, m, H arom.), 7.57-7.48 (3H, m, H arom.), 7.41-7.29 (5H, m, H arom.), 3.85 (2H, s, - $\mathrm{CH}_{2}$-napht.), 3.74 (2H, s, $-\mathrm{CH}_{2}$-benz.), 3.51-3.47 (2H, t, J = 5.28 Hz), 3.33 (2H, $\left.\mathrm{s},-\mathrm{CH}_{2}-\mathrm{CO}\right), 3.24-3.21\left(2 \mathrm{H}, \mathrm{t}, \mathrm{J}=5.28 \mathrm{~Hz},-\mathrm{N}-\mathrm{CH}_{2}\right), 1.61-1.51\left(4 \mathrm{H}, \mathrm{m},-\mathrm{N}_{-} \mathrm{CH}_{2}-\mathrm{CH}_{2}-\right), 1.46-1.42(2 \mathrm{H}$, m, - $\mathrm{CH}_{2}$-piper.). ${ }^{13} \mathrm{C} \mathrm{NMR}(50 \mathrm{MHz}, \mathrm{DMSO}-\mathrm{d6}): \delta 180.02,145.90,132.79,131.97,129.10,128.63$, 
$128.43,127.97,127.00,58.93,45.51,42.66,25.43,25.00,23.77$. Synthesis of the salt. HRMS m/z

$2(\mathrm{M}+\mathrm{H})^{+} 373.2274$.

[Benzyl-(2-naphthylmethyl)-amino]-(N'-methyl)-piperazido-acetamide hydrochloride (27).

4 Prepared from N-methylpiperazine (62 mg, $0.62 \mathrm{mmol})$, acid 18 (200 mg, $0.59 \mathrm{mmol})$, BOP (273 mg, $0.62 \mathrm{mmol})$ and NMM (130 $\mathrm{mg}, 1.29 \mathrm{mmol})$ using the general procedure for the synthesis of amides.

6 The resulting product was purified by flash chromatography with AcOEt/MeOH/TEA (9/1/2\%) to yield 7 a white powder $(168 \mathrm{mg}, 67 \%) . \mathrm{Rf}=0.3(\mathrm{AcOEt} / \mathrm{MeOH} / \mathrm{TEA}=9 / 1 / 2 \%) .{ }^{1} \mathrm{H} \mathrm{NMR}\left(300 \mathrm{MHz}, \mathrm{CDCl}_{3}\right): \delta$ 8 7.91-7.88 (3H, m, H arom.), 7.77 (1H, s, $\mathrm{H}$ arom.), 7.54-7.48 (3H, m, $\mathrm{H}$ arom.), 7.37-7.32 (5H, m, $\mathrm{H}$ 9 arom.), 3.87 (2H, s, - $\mathrm{CH}_{2}$-napht.), $3.76\left(2 \mathrm{H}, \mathrm{s},-\mathrm{CH}_{2}\right.$-benz.), 3.61-3.55 (2H, t, J= 4.9Hz, $\left.-\mathrm{CH}_{2}-\mathrm{NCO}\right)$, 10 3.36-3.32 (4H, m, - $\left.\mathrm{CH}_{2}-\mathrm{CO}-\mathrm{N}-\mathrm{CH}_{2}-\right), 2.38-2.29\left(7 \mathrm{H}, \mathrm{m},-\mathrm{CH}_{2}-\mathrm{NCH}_{3}-\mathrm{CH}_{2}-\right) .{ }^{13} \mathrm{C} \mathrm{NMR}(50 \mathrm{MHz}$ DMSO-d6): $\delta 164.99,135.64,134.82,133.52,133.05,131.88,130.53,129.87,129.36,129.21,128.64$, 128.29, 61.11, 54.10, 52.98, 44.03, 43.21, 40.40. Synthesis of the salt. HRMS m/z $(\mathrm{M}+\mathrm{H})^{+} 388.2383$. Prepared from N-phenylpiperazine (100 mg, $0.65 \mathrm{mmol})$, acid 18 (200 mg, $0.59 \mathrm{mmol})$, BOP (273 mg, $0.62 \mathrm{mmol})$ and NMM (130 $\mathrm{mg}, 1.29 \mathrm{mmol})$ using the general procedure for the synthesis of amides. powder $(240 \mathrm{mg}, 84 \%) . \mathrm{Rf}=0.25(\mathrm{Hexane} / \mathrm{AcOEt}=7 / 3) .{ }^{1} \mathrm{H}$ NMR $\left(300 \mathrm{MHz}, \mathrm{CDCl}_{3}\right): \delta 7.92-7.87(3 \mathrm{H}$, m, $\mathrm{H}$ arom.), 7.77 (1H, s, $\mathrm{H}$ arom.), 7.54-7.47 (3H, m, H arom.), 7.37-7.32 (7H, m, H arom.), 6.95-6.89 (3H, m, H arom.), 3.87 (2H, s, - $\mathrm{CH}_{2}$-napht.), $3.76\left(2 \mathrm{H}, \mathrm{s},-\mathrm{CH}_{2}\right.$-benz. $), 3.74-3.72\left(2 \mathrm{H}, \mathrm{m},-\mathrm{CH}_{2}-\mathrm{N}-\right.$ phenyl), 3.47-3.45 (2H, m, - $\mathrm{CH}_{2}-\mathrm{N}-$ phenyl), $3.35\left(2 \mathrm{H}, \mathrm{s},-\mathrm{CH}_{2}-\mathrm{CO}\right), 3.13-3.10(2 \mathrm{H}, \mathrm{t}, \mathrm{J}=5.3 \mathrm{~Hz},-\mathrm{CO}-$ NH- $\left.\mathrm{CH}_{2}-\right)$, 3.03-3.00 (2H, t, J = 5.0 Hz, -CO-NH-CH $\left.2_{2}\right) .{ }^{13} \mathrm{C}$ NMR (50 MHz, DMSO-d6): $\delta$ 163.27, $149.35,133.48,132.78,132.09,131.96,130.04,129.48,129.14,128.73,128.66,128.48,127.97$, $127.55,127.03,121.55,117.20,58.82,50.47,49.06,43.99,43.99,41.07$. Synthesis of the salt. $\mathrm{Mp}=$ $100{ }^{\circ} \mathrm{C} . \mathrm{HRMS} \mathrm{m} / \mathrm{z}(\mathrm{M}+\mathrm{H})^{+} 450.2540$.

[Benzyl-(2-naphthylmethyl)-amino]-3-pyridine hydrochloride (29). A solution of secondary amine 26 p (234 mg, $1 \mathrm{mmol})$, and $\mathrm{NaH}(48 \mathrm{mg}, 2 \mathrm{mmol})$ in $\mathrm{DMF}(0,3 \mathrm{M})$ was stirred at $0{ }^{\circ} \mathrm{C}$ few minutes then at 
1 RT during one hour. The benzylbromide (190 mg, 1,1 mmol) was added and the reaction was stirred

2 during one hour at $60{ }^{\circ} \mathrm{C}$ and reduced. The resulting oil was dissolved in AcOEt; the organic layer was

3 washed with a saturated solution of $\mathrm{NaHCO}_{3}(\mathrm{x} 2)$, water, saturated solution of $\mathrm{NaCl}$, then dried and

4 reduced. The resulting product was purified by flash chromatography with Hexane/AcOEt=7/3 to yield a

5 beige powder $(123 \mathrm{mg}, 34 \%) . \mathrm{Rf}=0.25(\mathrm{Hexane} / \mathrm{AcOEt}=7 / 3) .{ }^{1} \mathrm{H} \mathrm{NMR}\left(300 \mathrm{MHz}, \mathrm{CDCl}_{3}\right): \delta 8.32-$

68.29 (1H, d, H arom.), 8.05-8.01 (1H, m, H arom.), 7.92-7.75 (4H, m, H arom.), 7.62 (1H, s, H arom.),

7 7.50-7.45 (3H, m, H arom.), 7.40-7.20 (3H, m, H arom.), 7.07-7.03 (3H, m, H arom.), 4.86 (2H, s, - $\mathrm{CH}_{2}-$

8 napht.), 4.78 (2H, s, -CH2-benz.). ${ }^{13} \mathrm{C}$ NMR (50 MHz, DMSO-d6): $\delta 147.50,134.74,133.77,133.43$,

$9132.07,130.01,129.87,128.72,128.23,128.12,127.25,127.18,126.90,126.72,126.61,125.23$,

$124.73,124.38,55.39,55.16$. Synthesis of the salt. $\mathrm{Mp}=160^{\circ} \mathrm{C} . \mathrm{HRMS} \mathrm{m} / \mathrm{z}(\mathrm{M}+\mathrm{H})^{+} 325.1699$.

[Benzyl-(2-naphthylmethyl)-amino]-2-methylpyridine hydrochloride (30). Prepared from the secondary amine o (250 mg, 1 eq), benzylbromide (200 mg, $1.1 \mathrm{eq})$ and TEA (1.2 eq) using the general procedure for tertiary amines. The resulting product was purified by flash chromatography with Hexane/AcOEt $=9 / 1,8 / 2$ then $7 / 3$ to yield a yellow solid $(77 \%) . \mathrm{Rf}=0.15\left(\right.$ Hexane/AcOEt=9/1). ${ }^{1} \mathrm{H}$ NMR (300 MHz, $\left.\mathrm{CDCl}_{3}\right): \delta 8.06-8.04$ (1H, d, $\mathrm{H}$ arom.), 7.93-7.89 (4H, m, H arom.), 7.65-7.57 (3H, m, H arom.), 7.50-7.42 (4H, m, H arom.), 7.37-7.30 (2H, m, H arom.), 7.29-7.25 (1H, m, H arom.), 7.117.09 (1H, m, H arom.), 3.81 (2H, s, - $\mathrm{CH}_{2}$-pyr), 3.79 (2H, s, $-\mathrm{CH}_{2}$-napht.), 3.68 (2H, s, $-\mathrm{CH}_{2}$-benz.). ${ }^{13} \mathrm{C}$ NMR (50 MHz, DMSO-d6): $\delta$ 161.29, 142.82, 137.52, 129.59, 128.93, 127.98, 127.32, 125.79, 115.77, 57.66, 57.04. Synthesis of the salt. HRMS m/z (M+H) 339.1856 .

[Benzyl-(2-naphthylmethyl)-amino]-2-pyridine (31). A solution of secondary amine a (500 mg,1 eq), with $\operatorname{BuLi}(1.5 \mathrm{eq})$ in $\operatorname{DMF}(0,3 \mathrm{M})$ was stirred at $0{ }^{\circ} \mathrm{C}$ then cooled at $\mathrm{RT}$ during 1 h. 2Chloropyridine (253 mg, $1.1 \mathrm{eq}$ ) was added and the solution was stirred at RT during $1 \mathrm{~h}$ then at $60{ }^{\circ} \mathrm{C}$ overnight and reduced. The resulting oil was dissolved in AcOEt; the organic layer was washed with a saturated solution of $\mathrm{NaHCO}_{3}(\mathrm{x} 2)$, water, saturated solution of $\mathrm{NaCl}$, then dried and reduced. The resulting product was purified by flash chromatography with Hexane/AcOEt=7/3 to yield an oil (32\%). $\mathrm{Rf}=0.2($ Hexane/AcOEt=7/3). 1H NMR (300 MHz, CDCl3): $\delta 8.36-8.33(1 \mathrm{H}, \mathrm{d}, \mathrm{J}=6 \mathrm{~Hz}, \mathrm{H}$ arom. $)$, 
8.33-7.84 (3H, m, H arom.), 7.72 (1H, s, H arom.), 7.53-7.35 (9H, m, H arom.), 6.70-6.67 (1H, dd, J1 =

$25 \mathrm{~Hz}, \mathrm{~J} 2=1 \mathrm{~Hz}, \mathrm{H}$ arom.), 6.60-6.55 (1H, d, J = 8 Hz, H arom.), 5.04 (2H, s, -CH2-napht.), 4.93 (2H, s,

$3-\mathrm{CH}_{2}$-benz.). ${ }^{13} \mathrm{C}$ NMR (50 MHz, DMSO-d6): $\delta$ 159.04, 148.43, 138.78, 137.95, 136.32, 133.87,

$4133.11,112.78,106.44,78.03,77.45,76.82,51.49,51.26 . \mathrm{Mp}=76^{\circ} \mathrm{C} . \mathrm{HRMS} \mathrm{m} / \mathrm{z}(\mathrm{M}+\mathrm{H})^{+} 325.1540$.

[Benzyl-(2-naphthylmethyl)-amino]-4-pyrimidine hydrochloride (32). Prepared from the

6 secondary amine a $(350 \mathrm{mg}, 1.3 \mathrm{mmol}), 4$-chloropyrimidine (150 mg, $1.3 \mathrm{mmol})$ and TEA (150 mg, 1.5 mmol) using the general procedure for tertiary amines. The resulting product was purified by flash chromatography with Hexane/AcOEt $=5 / 5$ to yield a yellow solid $(250 \mathrm{mg}, 53 \%)$. $\mathrm{Rf}=0.2$ (Hexane/AcOEt=7/3). ${ }^{1} \mathrm{H}$ NMR $\left(300 \mathrm{MHz}, \mathrm{CDCl}_{3}\right): \delta 8.72(1 \mathrm{H}, \mathrm{s}, \mathrm{H}$ arom.), 8.28-8.17 $(1 \mathrm{H}, \mathrm{d}, \mathrm{J}=6 \mathrm{~Hz}$, H arom.), 7.86-7.75 (4H, m, H arom.), 7.60 (2H, m, H arom.), 7.50-7.46 (3H, m, H arom.), 7.40-7.25 (3H, m, H arom.), 6.48-6.45 (1H, d, J = 6 Hz, H arom.), 4.95 (2H, s, - $\mathrm{CH}_{2}$-napht.), 4.83 (2H, s, - $\mathrm{CH}_{2}-$ benz.). ${ }^{13} \mathrm{C} \mathrm{NMR}(50 \mathrm{MHz}, \mathrm{CDCl} 3): \delta 162.34,158.79,155.96,137.10,134.56,133.79,133.24,129.19$, $128.13,127.96,127.52,126.78,126.37,126.09,125.64,103.55,50.77,50.57,30.11$. Synthesis of the salt. HRMS m/z (M+H)+326.1652.

Biology.

Cloning. NK2R cDNA. Rat NK2R cDNA in 5' frame fusion with EGFP cDNA was cloned in pCEP4 expression vector (Invitrogen) as described. ${ }^{6}$

Cell culture and Buffer. HEK293 cells were stably transfected by calcium phosphate precipitation ${ }^{4}$ and selected with $500 \mu \mathrm{g} / \mathrm{ml}$ Hygromycin B. Cells were assayed in Hepes-BSA buffer $(137.5 \mathrm{mM} \mathrm{NaCl}$, 1.25mM MgCl2, 1.25mM CaCl2, 6mM KCl, 5.6mM glucose, 10mM Hepes, 0.4mM NaH2PO4, 1\% Bovine Serum Albumin (w/v), $\mathrm{pH}$ 7.4) supplemented with protease inhibitors. ${ }^{6}$

FRET measurements. Fluorescence binding. Interaction of fluorescent peptides with chimeric EGFPrNK2 was monitored on a Fluorolog 2 spectrofluorometer (SPEx) with excitation set at $470 \mathrm{~nm}$ (bandwidth $=5 \mathrm{~nm}$ ), as a decrease of EGFP emission at $510 \mathrm{~nm}$ (bandwidth $=10 \mathrm{~nm}$ ) reflecting fluorescence resonance energy transfer towards the acceptor group Bodipy as described. ${ }^{4}$ Cell (106 
cells $/ \mathrm{ml})$ or membrane suspensions $(100 \mu \mathrm{g} \cdot \operatorname{protein} / \mathrm{ml})$ in Hepes-BSA buffer were placed at $20{ }^{\circ} \mathrm{C}$ in a $1 \mathrm{ml}$-quartz cuvette under constant stinning. Addition of fluorescent agonist to the suspension results in a decrease of EGFP fluorescence at $510 \mathrm{~nm}$. The intensity of the fluorescence variation is proportional to receptor sites occupancy. Typically, saturation of receptor sites results in $40 \%$ decrease of total preparation fluorescence. Dissociation experiments are initiated by addition of an excess of unlabelled NKA $(1 \mu \mathrm{M})$ and recorded as a recovery of EGFP fluorescence intensity as a function of time.

Data analysis. The KaleidaGraphTM software was used for fitting NKAbo binding traces. Biexponential dissociation was defined by equation: $[\mathrm{F}]=\mathrm{f}(\mathrm{t})=\mathrm{A} 1 * \exp (-\mathrm{V} 1 * \mathrm{t})+\mathrm{A} 2 * \exp (-\mathrm{V} 2 * \mathrm{t})$. Where, $\mathrm{t}$ is the time in sec.; [F] is the FRET signal accounting for ligand bound to the receptor; V1 and V2 the off rate constants koff of respectively rapid and slow dissociation events in sec-1, A1 and A2 are the amplitudes of respectively rapid and slow dissociation.

Intracellular calcium determinations. Determinations were carried out as described. ${ }^{6,30}$ Briefly, adherent cells were loaded with $5 \mu \mathrm{M}$ Indo- 1 for $45 \mathrm{~min}$ at $37^{\circ} \mathrm{C}$, dissociated in PBS and suspended in Hepes buffer (in mM: $137.5 \mathrm{NaCl}, 1.25 \mathrm{MgCl} 2,1.25 \mathrm{CaCl} 2,6 \mathrm{KCl}, 5.6$ glucose, 10 Hepes, 0.4 $\mathrm{NaH} 2 \mathrm{PO} 4,1 \% \mathrm{BSA}(\mathrm{w} / \mathrm{v}), \mathrm{pH}$ 7.4) in Hepes buffer (in mM: $137.5 \mathrm{NaCl}, 1.25 \mathrm{MgCl} 2,1.25 \mathrm{CaCl} 2,6$ KCl, 5.6 glucose, 10 Hepes, $0.4 \mathrm{NaH} 2 \mathrm{PO} 4,1 \% \mathrm{BSA}$ (w/v), pH 7.4). Cell suspension measurements were made at $21^{\circ} \mathrm{C}$ in a $1-\mathrm{ml}$ cuvette on the SPEX Fluorolog 2 spectrofluorometer with excitation set at $355 \mathrm{~nm}$ and time-based emission detected at $405 \mathrm{~nm}$ and $475 \mathrm{~nm}$. Recordings were normalized according to the maximal intensity of fluorescence detected upon addition of the detergent digitonin and plotted as $475 / 405$ ratios. Data points reported in the figure correspond to the area under the response curve in arbitrary units.

cAMP measurements. Functional NK2R-mediated coupling to adenylyl cyclase was assessed by measuring the dose-dependent stimulatory effects of neurokinin A on cAMP accumulation. HEK293 cultures expressing NK2 receptors were harvested and seeded in 24-well plates coated with collagen (60 $\mathrm{mg} / \mathrm{ml})$ at an initial density of 50,000 . After 3 days of culture ( $\sim 80 \%$ confluency), the cells were treated as previously described ${ }^{6,30}$ The inhibitory effect of LPI805 and LPI827 on NKA-stimulated cAMP 
1 accumulation was determined in the presence of $10 \mu \mathrm{M}$ of each compound. The reaction was stopped by

2 addition of one volume ice-cold $0.2 \mathrm{M} \mathrm{HCl}$ and cAMP was determined by radioimmunoassay.

3

4 ACKNOWLEDGMENT. This work was supported by the Centre National de la Recherche

5 Scientifique, the Universite de Strasbourg and the European Community's Sixth Framework Program 6 (grant LSHB-CT-2003-503337).

8 SUPPORTING INFORMATION AVAILABLE: extended analytical data on the most potent 9 compounds are available free of charge via the Internet at http://pubs.acs.org. 

red trace.

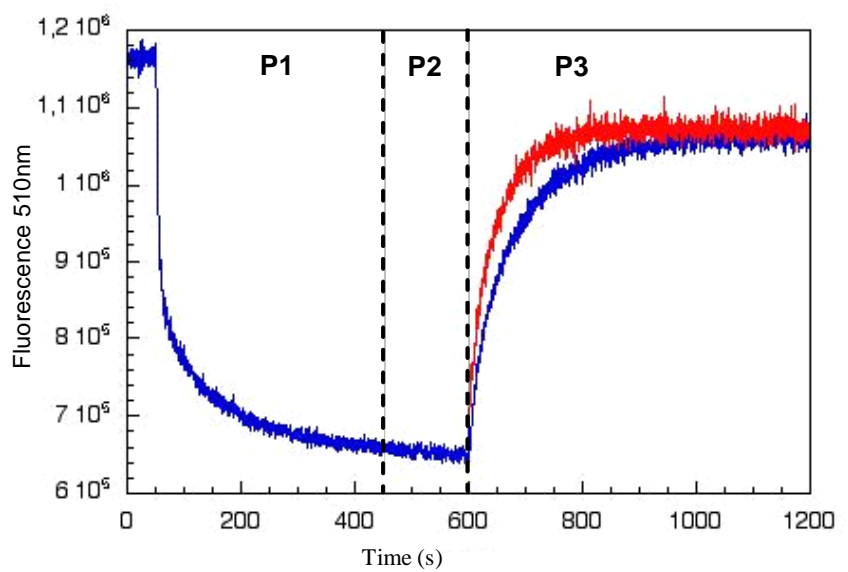

Figure 1. Principle of the FRE I-based assay exemplitied with compound 1. Association phase P1: at time $\mathrm{t}=50 \mathrm{~s}, 20 \mathrm{nM}$ NKA-Bo are added to a suspension of cells expressing EGFP-NK2R and association is followed as a decrease of EGFP fluorescence intensity at $510 \mathrm{~nm}$. Incubation with test compound phase P2: at $450 \mathrm{~s}$, the tested allosteric compound is added and equilibration is allowed to proceed for $150 \mathrm{~s}$. Dissociation phase P3: at $600 \mathrm{~s}, 20 \mu \mathrm{M}$ of the non fluorescent ligand NKA are added and NKA-Bo dissociation is recorded. In the absence of allosteric modulator, NKA-Bo dissociates according to the blue trace; in the presence of the allosteric compound $\mathbf{1}$, it dissociates according to the 19 


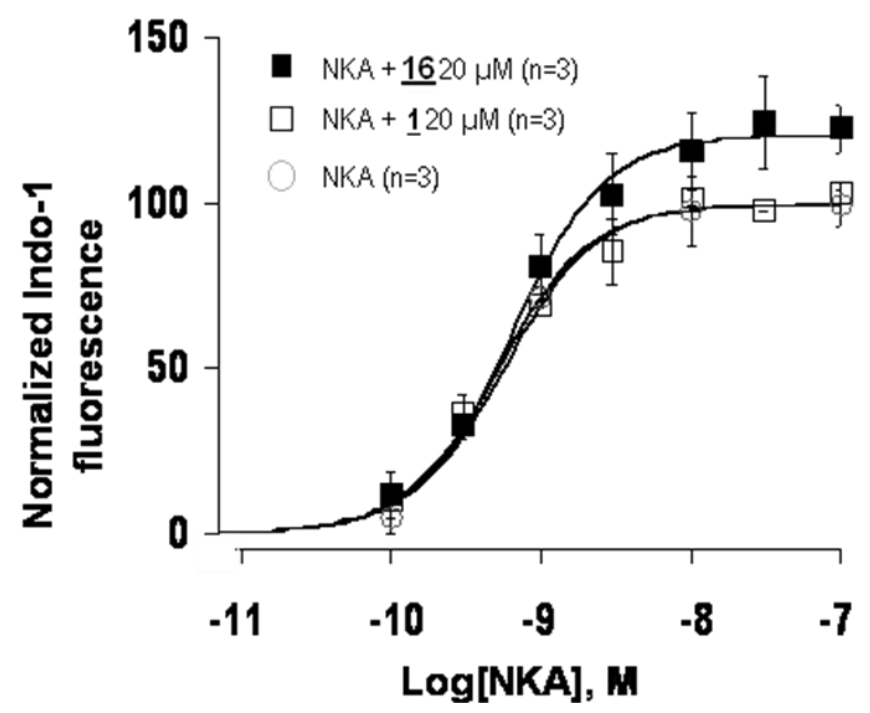

2

3 Figure 2. Effect of compounds 1 and $\mathbf{1 6}$ on NKA-evoked intracellular calcium. Intracellular calcium

4 release dose-response relationship to increasing concentrations of NKA (open circles, $\mathrm{EC}_{50}=0.55 \pm 0.05$

$5 \mathrm{nM}$ ) were recorded. The effect of the presence of compound 1 (open squares, $\mathrm{EC}_{50}=0.50 \pm 0.05 \mathrm{nM}$ ) or

6 compound 16 (filled squares, $\mathrm{EC}_{50}=0.62 \pm 0.04 \mathrm{nM}$ ) is shown. While compound 1 does not modify the

7 sensitivity to NKA nor the amplitude of the response, compound $\mathbf{1 6}$ enhances the amplitude of the 8 maximal response to $120 \pm 5 \%$. 


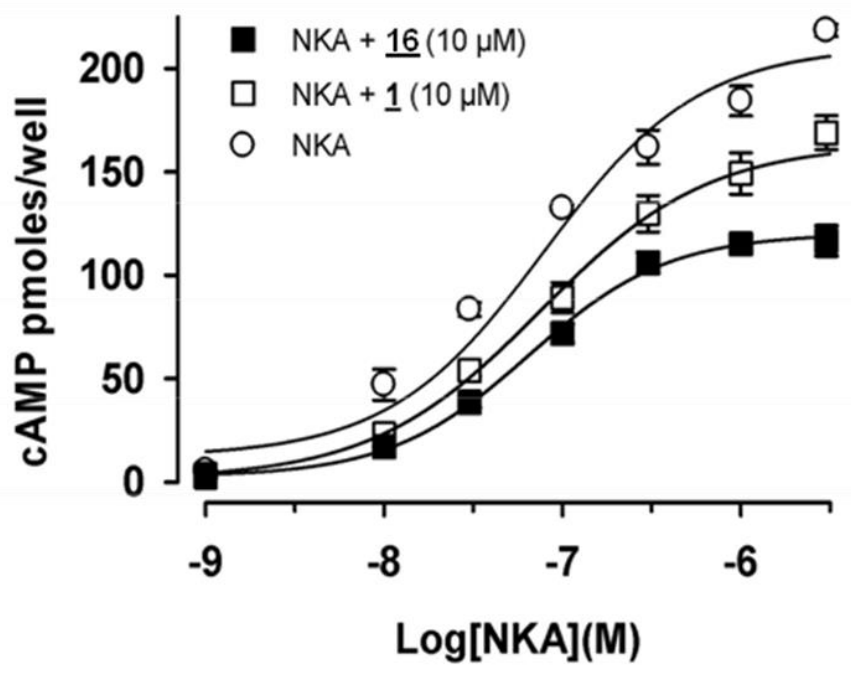

2

3 Figure 3. Effect of compounds 1 and 16 on NKA-evoked cAMP production in HEK cells. cAMP dose-

4 response relationship to increasing concentrations of NKA (open circles, $\mathrm{EC}_{50}=64.8 \pm 2.1 \mathrm{nM}$ ) were 5 recorded. The effect of the presence of $10 \mu \mathrm{M}$ compound 1 (open squares, $\mathrm{EC}_{50}=74.8 \pm 3.5 \mathrm{nM}$ ) or 6 compound 16 (filled squares, $\mathrm{EC}_{50}=64.8 \pm 1.4 \mathrm{nM}$ ) is shown. Each data point is the mean \pm s.d. of 6 7 determinations. Compound 1 reduces the maximal amplitude of the cAMP response by $33 \pm 5 \%$ and 8 compound 16 reduces it by $47 \pm 4 \%$ at the same concentration, showing improved activity over 9 compound $\mathbf{1}$. 


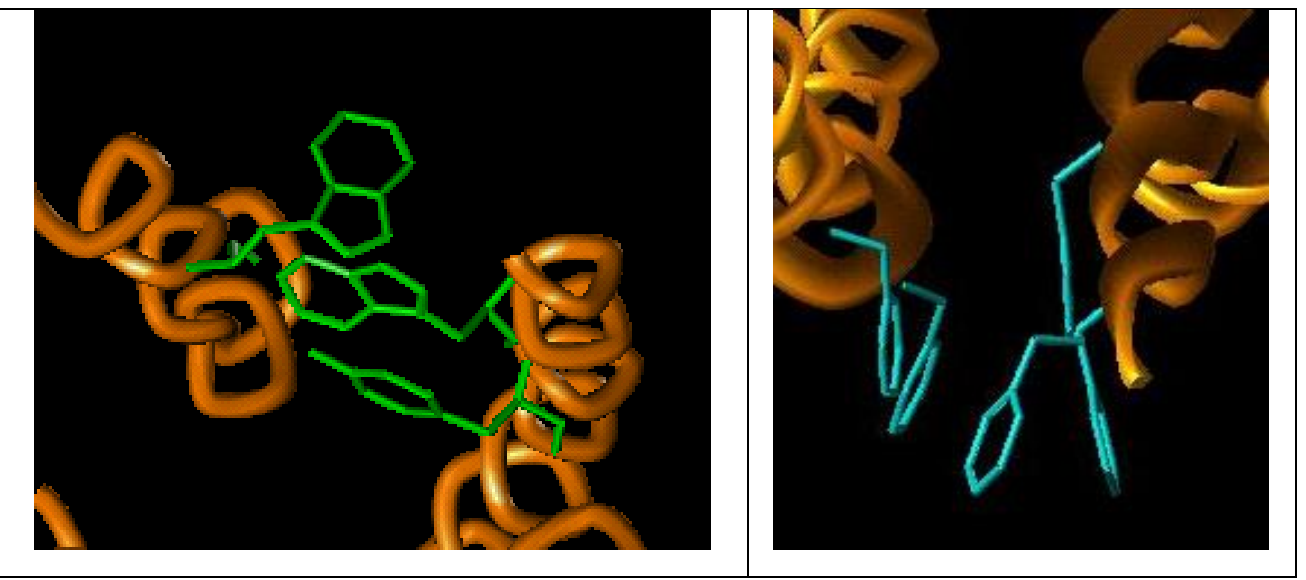

2

3 Figure 4. Two putative binding domains for NK2 receptor allosteric modulators (view from the outside

4 of the cell). The models have been built classically by homology with bovine opsin. ${ }^{31}$ Trp1.35, Tyr1.39

5 on the top of TM 1 and Tyr2.64 on the top of TM2 (green) form the first aromatic cluster, pointing 6 towards the entrance of the orthosteric binding cleft. Phe2.56, 2.60 (TM2) and Phe3.24, 3.27 and 3.31

7 (top of TM3), in blue, form the second aromatic cluster, pointing toward the outside of the receptor, in 8 the transmembrane region. Similar domains are obtained based on the most recent crystal structures of 9 adrenergic and adenosine receptors. ${ }^{32}$ 
5 Scheme 1. Synthesis of analogues of the allosteric modulator 1.

\section{Method A}

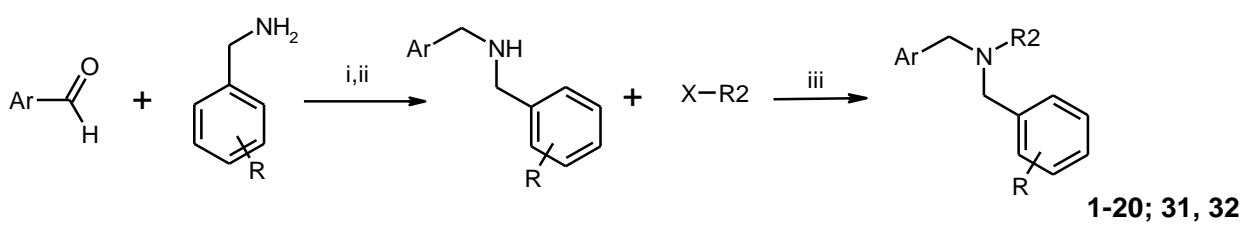

$18 \stackrel{\text { iv }}{\longrightarrow}$<smiles>[R6]c1ccc2ccccc2c1</smiles>

$1-20 ; 31,32$

6

Chart 1. Structure of 1, [N-Benzyl,N-(2-naphthylmethyl)-amino]-acetonitrile, and pharmacomodulation positions (in circles). 


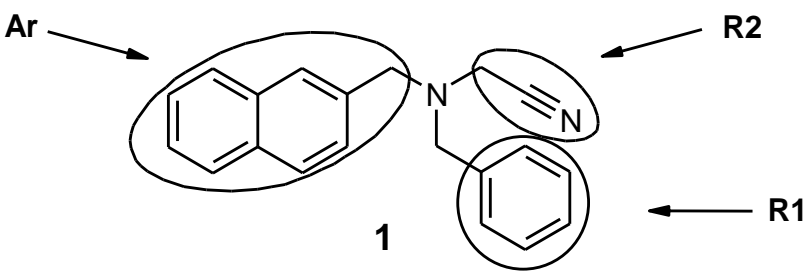

2 Table 1. Percentages of $\mathrm{NK}_{2}-\mathrm{R}$ active conformations $\mathrm{A} 1$ and $\mathrm{A} 2$ with or without compound 1 in 3 presence of $20 \mathrm{nM}$ NKA-Bo.

\begin{tabular}{|c|c|c|}
\hline & Quick Dissociation (A1 conformation) & Slow Dissociation (A2 conformation) \\
\hline Without $\mathbf{1}$ & $30 \%$ & $70 \%$ \\
\hline $\mathbf{1}$ at $10 \mu \mathrm{M}$ & $50 \%$ & $50 \%$ \\
\hline $\mathbf{1}$ at $50 \mu \mathrm{M}$ & $95 \%$ & $5 \%$ \\
\hline
\end{tabular}

5 Table 2. Allosteric activity of 1 and of its benzyl-analogues, at $10 \mu \mathrm{M}$ in a kinetic FRET-based assay.

\begin{tabular}{|c|c|c|c|c|}
\hline $\mathrm{N}^{\circ}$ & $\mathrm{R} 1$ & $\%$ of A1 conformation. & FRET inhibition $^{\mathrm{b}}$ & $\mathrm{n}^{\mathrm{c}}$ \\
\hline $\mathbf{1}$ & Benzyl & $50 \% \pm 3$ & $0 \%$ & 10 \\
\hline $\mathbf{2}$ & 4-Bromobenzyl & $45 \% \pm 1$ & $0 \%$ & 3 \\
\hline $\mathbf{3}$ & 2-Bromobenzyl & $43 \% \pm 2$ & $0 \%$ & 3 \\
\hline $\mathbf{4}$ & 4-Iodobenzyl & $47 \% \pm 3$ & $0 \%$ & 3 \\
\hline $\mathbf{5}$ & Phenethyl & $39 \%$ & $0 \%$ & 1 \\
\hline $\mathbf{6}$ & 4-Methoxybenzyl & $54 \% \pm 1$ & & 2 \\
\hline
\end{tabular}

6

7 a Percentage of A1 conformation, evaluated with a two exponential equation. ${ }^{\mathrm{b}}$ FRET inhibition, 8 expressed as a percentage of the reversal in FRET caused by the NKA. ${ }^{\mathrm{c}} \mathrm{n}$, number of experiments. 
1 Table 3. Allosteric activity of naphthyl-analogues of $\mathbf{1}$, at $10 \mu \mathrm{M}$ in a kinetic FRET-based assay.

\begin{tabular}{|c|c|c|c|c|}
\hline $\mathrm{N}^{\circ}$ & Ar & $\%$ of A1 conformation. & FRET inhibition $^{\mathrm{b}}$ & $\mathrm{n}^{\mathrm{c}}$ \\
\hline $\mathbf{1}$ & Benzyl & $50 \% \pm 3$ & $0 \%$ & 10 \\
\hline $\mathbf{7}$ & 3-Chlorobenzyl & $45 \%$ & $0 \%$ & 1 \\
\hline $\mathbf{8}$ & 4-Chlorobenzyl & $53 \%$ & $0 \%$ & 1 \\
\hline $\mathbf{9}$ & (1H)Indol-3ylmethyl & - & - & 1 \\
\hline $\mathbf{1 0}$ & Quinolin-2-ylmethyl & $47 \% \pm 4$ & $21 \%$ & 3 \\
\hline $\mathbf{1 1}$ & Quinolin-3-ylmethyl & $46 \% \pm 4$ & $0 \%$ & 3 \\
\hline $\mathbf{1 2}$ & Cinnamyl & $47 \% \pm 3$ & $0 \%$ & 3 \\
\hline $\mathbf{1 3}$ & 4-Methoxybenzyl & $49 \% \pm 2$ & $0 \%$ & 3 \\
\hline $\mathbf{1 4}$ & 4-Trifluoromethylbenzyl & $48 \% \pm 3$ & & 3 \\
\hline
\end{tabular}

2

3 a Percentage of A1 conformation, evaluated with a two exponential equation. ${ }^{\mathrm{b}}$ FRET inhibition, 4 expressed as a percentage of the reversal in FRET caused by the NKA. ${ }^{c} n$, number of experiments. 
1 Table 4. Allosteric activity of acetonitrile analogues of $\mathbf{1}$, at $10 \mu \mathrm{M}$ in a kinetic FRET-based assay.

\begin{tabular}{|c|c|c|c|c|}
\hline $\mathrm{N}^{\circ}$ & $\mathrm{R} 2$ & $\%$ of A1 conformation. ${ }^{a}$ & FRET inhibition $^{b}$ & $\mathrm{n}^{\mathrm{c}}$ \\
\hline 15 & Propargyl & $51 \% \pm 6$ & $0 \%$ & 3 \\
\hline 16 & Butyronitril & $68 \% \pm 1$ & $0 \%$ & 3 \\
\hline 17 & Ethyl ethanoate & $51 \% \pm 6$ & $0 \%$ & 3 \\
\hline 18 & Acetic acid & $35 \% \pm 2$ & $0 \%$ & 3 \\
\hline 19 & Ethyl pentoate & $52 \% \pm 3$ & $0 \%$ & 3 \\
\hline 20 & Pentanoic acid & $44 \% \pm 3$ & $0 \%$ & 3 \\
\hline 21 & Hexadecanoyl ethanoate & $38 \% \pm 0$ & $0 \%$ & 2 \\
\hline 22 & Phenethyl ethanoate & $46 \% \pm 2$ & $0 \%$ & 3 \\
\hline 23 & 2-Hydroxyethyl ethanoate & $53 \% \pm 3$ & $0 \%$ & 3 \\
\hline 24 & Morpholinoethyl ethanoate & $42 \% \pm 2$ & $0 \%$ & 4 \\
\hline 25 & Butyl acetamide & $54 \% \pm 2$ & $0 \%$ & 3 \\
\hline 26 & Piperidino-acetamide & $44 \%$ & $0 \%$ & 1 \\
\hline 27 & N-Methylpiperazino-acetamide & $58 \%$ & $0 \%$ & 1 \\
\hline 28 & N-Phenylpiperazino-acetamide & $43 \% \pm 2$ & $0 \%$ & 3 \\
\hline 29 & 3-Pyridine & $59 \% \pm 2$ & $0 \%$ & 2 \\
\hline 30 & 2-methylpiridine & $51 \% \pm 1$ & $24 \%$ & 3 \\
\hline 31 & 2-Pyridine & $56 \% \pm 4$ & $17 \%$ & 2 \\
\hline 32 & 4-Pyrimidine & $61 \% \pm 3$ & $34 \%$ & 3 \\
\hline
\end{tabular}

2 a Percentage of A1 conformation, evaluated with a two exponential equation. ${ }^{\mathrm{b}}$ FRET inhibition, 3 expressed as a percentage of the reversal in FRET caused by the NKA. ${ }^{c} n$, number of experiments. 
(1) Christopoulos, A. Allosteric binding sites on cell-surface receptors: novel targets for drug discovery. Nat. Rev. Drug Discovery 2002, 1, 198-210.

(2) May L.T.; Leach K.; Sexton P.M.; Christopoulos, A. Allosteric modulation of G protein-coupled receptors. Annu. Rev. Pharmacol. Toxicol. 2007, 47, 1-51.

(3) (a) Forster, T. Energiewanderung und fluoreszenz. Naturwissenschaften 1946, 6, 166-175. (b)

7 Clegg, R. M. Fluorescence energy transfer. Curr. Opin. Biotechno. 1995, 6, 103-110.

(4) Vollmer, J.Y.; Alix, P.; Chollet, A.; Takeda, K.; Galzi, J.L. Subcellular compartmentalization of activation and desensitization of responses mediated by NK2 neurokinin receptors. J. Biol. Chem. 1999, $10 \quad 274,37915-37922$.

(5) Zimmer, M. Green fluorescent protein (GFP): applications, structure and related photophysical behaviour. Chem. Rev. 2002, 102, 759-781.

(6) Palanche, T.; Ilien, B.; Zoffmann, S.; Reck, M.P.; Bucher, B.; Edelstein, S.J.; Galzi, J.L. The neurokinin A receptor activates calcium and cAMP responses through distinct conformational states. $J$. Biol. Chem. 2001, 276, 34853-34861.

(7) Ilien, B.; Franchet, C.; Bernard, P.; Morisset, S.; Weill, C.O.; Bourguignon, J.J.; Hibert, M.; Galzi, J.L. Fluorescence resonance energy transfer to probe human M1 muscarinic receptor structure and drug binding properties. J. Neurochem. 2003, 85, 768-778.

(8) Maillet, E.L. ; Pellegrini, N. ; Valant, C. ; Bucher, B. ; Hibert, M. ; Bourguignon, J.J. ; Galzi, J.L. A novel conformation specific allosteric inhibitor of the tachykinin NK2 receptor (NK2R) with functionally selective properties, FASEB J. 2007, 21, 2124-2134. a receptor. WO Patent 03107004, December 2003. 
(10) Palczewski, K.; Kumasaka, T.; Hori, T.; Behnke, C.A.; Motoshima, H.; Fox, B.A.; Le Trong, I.;

2 Teller, D.C.; Okada, T.; Stenkamp, R.E.; Yamamoto, M.; Miyano, M. Crystal structure of Rhodopsin: a

3 G protein coupled receptor. Science 2000, 289, 739-745.

(11) Bhogal, N.; Donnelly, D.; Findlay, J.B. The ligand binding site of the neurokinin 2 receptor. Sitedirected mutagenesis and identification of neurokinin A binding residues in the human neurokinin 2 receptor. J. Biol. Chem. 1994, 269, 27269-27274.

(12) Labrou, N.E.; Bhogal, N.; Hurrell, C.R.; Findlay, J.B. Interaction of Met297 in the seventh transmembrane segment of the tachykinin NK2 receptor with neurokinin A. J Biol Chem. 2001, 276, 37944-9.

(13) Milligan, G.; Smith, N.J. Allosteric modulation of heterodimeric G-protein coupled receptors. Trends Pharmacol Sci. 2007, 28, 615-20.

(14) Milligan, G.; Bouvier, M. Methods to monitor the quaternary structure of G protein-coupled receptors. FEBS J. 2005, 272, 2914-2925.

(15) Cherezov, V.; Rosenbaum, D. M.; Hanson, M. A.; Rasmussen, S.; Thian, F.; Kobilka, T. S.; Choi, H.-J.; Kuhn, P.; Weis, W.; Kobilka, B.; Stevens, R. High-Resolution Crystal Structure of an Engineered Human $\beta 2$-Adrenergic G Protein-Coupled Receptor. Science 2007, 318, 1258-1265.

(16) Warne, T.; Maria, J.; Serrano-Vega, M.; Baker, J.; Moukhametzianov, R; Edwards, P.; Henderson, R.; Leslie, A.; Tate, C.; Schertler, G. Structure of a $\boldsymbol{\beta}$ 1-adrenergic G-protein-coupled receptor. Nature 2008, 454, 486-491.

(17) Veli-Pekka Jaakola, V.; Griffith, M.; Hanson, M.; Cherezov, V.; Chien, E.; Lane, R.; IJzerman, A.; Stevens, R. The 2.6 Angstrom Crystal Structure of a Human A2A Adenosine Receptor Bound to an Antagonist. Science 2008, 322, 1211-1217. 
(18) Springael, J.-Y.; Urizar, E.; Costagliola, S.; Vassart, G.; Parmentier, M. Allosteric properties of G 2 protein coupled receptor oligomers. Pharmaco. Ther. 2007, 115, 410-418.

(19) Adham, N.; Ellerbrock, B.; Hartig, P.; Weinshank, R. L.; Branchek, T. Receptor reserve masks partial agonist activity of drugs in a cloned rat 5-hydroxytryptamine1B receptor expression system. Mol. Pharmacol. 1993, 43, 427-433.

(20) Whaley, B. S.; Yuan, N.; Birnbaumer, L.; Clark, R. B.; Barber, R. Differential expression of the beta-adrenergic receptor modifies agonist stimulation of adenylyl cyclase: a quantitative evaluation. Mol. Pharmacol. 1994, 45, 481-489.

(21) Soudijn, W.; van Wijngaarden, I.; IJzerman, A. Allosteric modulation of G protein coupled receptors: perspectives and recent developments. Drug Discovery Today 2004, 9, 752-758.

(22) Leach, K.; Sexton, P. M.; Christopoulos, A. Allosteric GPCR modulators: taking advantage of permissive receptor pharmacology. Trend Pharmacol. Sci. 2007, 28, 382-389.

(23) Schwartz, T.; Holst, B. Allosteric enhancers, allosteric agonists and ago-allosteric modulators: where do they bind and how do they act? Trends Pharmacol. Sci. 2007, 28, 367-373.

(24) Neubig, R. R.; Spedding, M.; Kenakin, T.; Christopoulos; A. International Union of terms and symbols in quantitative pharmacology. Pharmacol. Rev. 2003, 55, 597-606.

(25) Urban, J. D.; Clarke, W. P.; von Zastrow, M.; Nichols, D.E.; Kobilka, B.; Weinstein, H.; Javitch, 19 J. A.; Roth, B. L.; Christopoulos, A.; Sexton, P. M.; Miller, K. J.; Spedding, M.; Mailman, R. B. 20 Functional selectivity and classical concepts of quantitative pharmacology. J. Pharmacol. Exp. Ther.. 2007, 320, 1-13.

(26) Kenakin, T. Agonist-receptor efficacy. II. Agonist trafficking of receptor signals. Trends 23 
(27) Hermans, E. Biochemical and pharmacological control of the multiplicity of coupling of G 2 protein coupled receptors. Pharmacol. Ther. 2003, 99, 25-44.

(28) Tateyama, M.; Kubo, Y. Dual signalling is differentially affected by different active states of the 4 metabotropic glutamate receptor $1 \alpha$. Proc. Natl. Acad. Sci. U. S. A. 2006, 103, 1124-1128.

(29) Aurelio, L.; Valant, C.; Flynn, B.; Sexton, P.; Christopoulos, A.; Scammells, P. Allosteric modulators of the adenosine A1 receptor : synthesis and pharmacological evaluation of 4 substituted 2amino-3-bezoylthiophenes. J. Med. Chem. 2009, 52, 4543-4547.

(30) Lecat, S., Bucher, B., Mely, Y. and Galzi, J.L. Mutations in the extracellular amino-terminal domain of the NK2 neurokinin receptor abolish cAMP signaling but preserve intracellular calcium responses. J. Biol. Chem. 2002, 277, 42034-42048.

(31) K. Palczewski, T. Kumasaka, T. Hori, C.A. Behnke, H. Motoshima and B.A. Fox et al., Crystal structure of rhodopsin: a G protein-coupled receptor. Science 2000, 289, 739-745. 
TABLE OF CONTENTS GRAPHIC

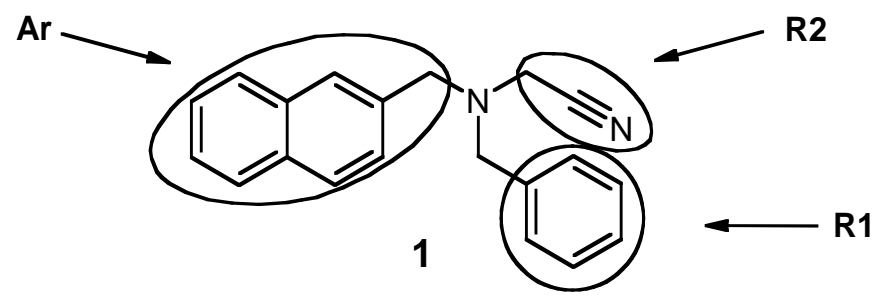

